\title{
Mitigation Banks and Other Conservation Lands at Risk from Preferential Groundwater Flow and Hydroperiod Alterations by Existing and Proposed Northeast Florida Mines
}

\author{
Sergio Bernardes ${ }^{1}$, Jiaying He ${ }^{1}$, Sydney T. Bacchus ${ }^{1}$, Marguerite Madden ${ }^{1} \&$ Thomas Jordan ${ }^{1}$ \\ ${ }^{1}$ Center for Geospatial Research, Department of Geography, University of Georgia, Athens, USA \\ Correspondence: Marguerite Madden, Center for Geospatial Research, Department of Geography, University of Georgia, \\ Athens, Georgia 30602-2502 USA. E-mail: mmadden@uga.edu
}

Received: April 3, 2014 Accepted: April 11, 2014 Online Published: July 31, 2014

doi:10.5539/jsd.v7n4p225

URL: http://dx.doi.org/10.5539/jsd.v7n4p225

\begin{abstract}
When evaluating applications for proposed projects, agencies in the United States (U.S.) must consider mitigation options for the destruction of the aquatic environment such as wetlands, if no practicable alternative to the proposed action exists. Because attempts to create artificial wetlands as replacements for natural wetlands that were destroyed have had little success, particularly in the case of forested wetlands, mitigation options often include mitigation banks and conservation restrictions as permit requirements. In Florida, agencies issuing permits for projects involving groundwater alterations such as withdrawals from wells and mining, do not require an analysis of how on-site and off-site wetlands designated as mitigation, conservation or preservation for destroyed wetlands would be affected by fractures and other karst features that occur throughout the Floridan aquifer system (FAS). This study analyzed the underlying geological conditions in the FAS using lineaments as surface expressions of those conditions, in addition to indicators of preferential groundwater flow in an environmentally sensitive karst area of northeast Florida, including Baker and Clay Counties, where extensive mining has occurred in the recent past and more extensive mining is proposed in the immediate future. Established methods, such as spatial matching of scanned maps and remotely sensed images and control-point identification, were used for georectification of the analog maps. These techniques were applied to surface expressions of underlying fractures that were mapped in the early 1950s and 1970s, prior to extensive groundwater extractions, urbanization and mining in the region. The vegetation changes and reduced groundwater discharges from those alterations reduce the ability to identify fractures from post-development images. Geospatial analyses of lineament distribution revealed that the study area and surrounding counties included a dense network of lineaments, including through existing and proposed mines, mitigation banks and other conservation lands. Excavation, water use and operation of proposed mines associated with those fractures could result in irreversible adverse environmental impacts to those mitigation banks and other conservation lands linked by the network of fractures. To ensure sustainable developments and compliance with mitigation laws in this highly fractured area, adverse impacts to mitigation banks and other conservation lands from groundwater pumping and mining via fractures must be considered.
\end{abstract}

Keywords: dolines, fractures, georectified lineaments, geospatial analysis, GIS, induced recharge, karst, sinkholes

\section{Introduction}

\subsection{Mitigation Requirements and Current Approach to Project Evaluation and Mitigation}

Federal agencies must consider mitigation options when evaluating applications for proposed projects if no practicable alternative exists for the destruction of the aquatic environment, such as wetlands. A proposed project is contrary to the public interest if it fails to comply with the Clean Water Act (CWA) Section 404(b)(1) Guidelines. One of the public-interest factors considered in the Code of Federal Regulations (CFR) is mitigation, including avoiding, minimizing, rectifying, reducing, or compensating for resource losses (33 CFR $\$ 320.4(\mathrm{r})$ ). The National Environmental Policy Act (NEPA) includes a broad definition of mitigation as (40 CFR §1508.20):

(a) Avoiding the impact altogether by not taking a certain action or parts of an action;

(b) Minimizing the impacts by limiting the degree or magnitude of the action and its implementation;

(c) Rectifying the impact by repairing, rehabilitating, or restoring the affected environment;

(d) Reducing or eliminating the impact over time by preservation and maintenance operations during the life of the action; and

(e) Compensating for the impact by replacing or providing substitute resources or environments. 
Federal regulations governing compensatory mitigation for impacts to wetlands, streams, and other waters of the U.S. permitted under the CWA were revised on March 31, 2008, in the Compensatory Mitigation Rule or the 2008 Mitigation Rule (33 CFR Parts 325 and 332 and 40 CFR Part 230), to address "no net loss" of wetlands. Florida law also addresses mitigation and mitigation banks. For example, Florida Statutes (F.S.) Chapter 373.4135 regulates mitigation banks and offsite regional mitigation and Chapter 373.4136 F.S. addresses establishment, operation and permitting of mitigation banks (http://www.leg.state.fl.us/statutes/). Both federal and state mitigation options in Florida frequently include mitigation banks and conservation restrictions placed on lands because attempts to create wetlands, particularly forested wetlands, to replace natural wetlands that were destroyed have had poor success (Turner, Redmond, \& Zedler, 2001). Some requirements for obtaining a permit for a mitigation bank in Florida include reasonable assurance provided by the applicant that (373.4136(1) F.S.):

(a) The proposed mitigation bank will improve ecological conditions of the regional watershed;

(b) The proposed mitigation bank will provide viable and sustainable ecological and hydrological functions for the proposed mitigation service area;

(c) The proposed mitigation bank will be effectively managed in perpetuity;

(d) The proposed mitigation bank will not destroy areas with high ecological value;

(e) The proposed mitigation bank will achieve mitigation success;

(f) The proposed mitigation bank will be adjacent to lands that will not adversely affect the perpetual viability of the mitigation bank due to unsuitable land uses or conditions;

Karst aquifers occur throughout the U.S., as depicted in the map prepared by the American Geosciences Institute (www.agiweb.org/environment/karstmap.pdf). The regional karst Floridan aquifer system (FAS) is one of the largest karst aquifer systems in the U.S., underlying the entire state of Florida and southeastern coastal plain portions of Alabama, Georgia and South Carolina (Krause \& Randolph, 1989; Miller, 1986). Currently, agencies permitting projects in areas of karst aquifers in the U.S. involving groundwater alterations, such as withdrawals from wells and mining, do not include an analysis of how on-site and off-site wetlands designated as mitigation, conservation or preservation for destroyed wetlands will be affected by fractures and other karst features, such as sinkholes. Recent examples by federal agencies within the regional FAS include the Final Areawide Environmental Impact Statement (EIS) for proposed expansion of phosphate mining in west-central Florida (U.S. Army Corps of Engineers [USACE], 2013) and the draft and Final EIS for the proposed Levy County Nuclear Power Plant, Units 1 and 2 (U.S. Nuclear Regulatory Commission [USNRC], 2010; 2012). A recent example in the same regional karst aquifer system by state agencies includes the State of Florida, Division of Administrative Hearings (DOAH) April 11, 2013 ruling on the 1,575.5-acre Highlands Ranch Mitigation Bank (http:/www.doah.state.fl.us/ALJ/, Case No. 12-3219). This mitigation bank, also known as the Highlands Mitigation Bank, is located adjacent to the initial DuPont Trail Ridge Mine in Clay County, Florida.

\subsection{Evidence of Fractures in Aerial Photographs and Satellite Imagery and Influence on Preferential Groundwater Flow}

A detailed synopsis of the peer-reviewed published literature describing the use of aerial photographs and satellite imagery to identify extensions of subsurface fractures, including faults, is provided by Lines et al. (2012). The authors provide also an in-depth discussion of the influence of fractures, karst conduits and sinkholes on preferential groundwater flow, based on peer-reviewed published literature. Our use of terms treats sinkholes as synonymous with dolines and is consistent with the definitions provided in that 2012 publication for terms such as lineaments, fracture traces, and photolinears, with references to fractures as inclusive of faults and joints (fractures without movement).

\subsection{Case Study of the Flawed Approach to Mitigation in a Regional Karst Aquifer System}

Because the FAS is one of the largest regional karst aquifer systems in the U.S., this aquifer was selected as the focus for our case study. This regional karst aquifer system is the source of water, both directly and indirectly, for the majority of developments in Florida (Fernald \& Purdum, 1998; Johnston \& Miller, 1988; Miller, 1986) and consists of limestones that have been subjected to multiple karst cycles (Upchurch \& Lawrence, 1984). Because of the karstic conditions of this aquifer system, the standard practice in investigations of foundation stability, sinkhole probability, and groundwater availability should involve delineation of photolinear features that may predispose affected areas to instability and high transmissivities (Lattman \& Parizek, 1964; Littlefield, Culbreath, Upchurch, \& Stewart, 1984; Parizek, 1976). For sinkhole analysis, Ogden (1984) recommended: (a) delineation from topographic maps and aerial photographs; (b) analysis of depth, width and elongation, including statistical comparison to fractures (joints and faults) and photo-lineament trends; (c) analysis of topography; (d) water-table monitoring; (e) identification of deformation for man-made structures, ponding of rainwater and vegetation stress; (f) geophysical analysis (e.g., resistivity, seismic reflection) of shallow features; and (g) identification of mining, impoundments, groundwater pumping and other water diversions.

Our review of EIS and Environmental Assessments (EA) documents for proposed projects in Florida over the past 30 years 
indicates that despite the standard practice and published procedures, and the fact that existing and proposed mines in Florida would include all of the factors described in (g) of Ogden (1984) that induce sinkholes, agencies routinely do not consider environmental impacts associated with preferential groundwater flow pathways in the karst aquifer system off-site, beyond the surface footprint of proposed projects, or even on the site. Instead, projects such as those described above, are permitted in Florida by local, district, state and federal governments without these investigations or evaluations of groundwater impacts or groundwater models that evaluate impacts to or from preferential groundwater flow via fractures and karst conduits, which are associated with modern and relict sinkholes (synonymous with paleosinks for our study), as described by Bacchus, Masour, Madden, Jordan, and Meng (2011), because these features are not represented accurately in a published database. Therefore, adverse impacts to on-site and off-site wetlands, mitigation areas and other conservations lands cannot be considered due to preferential groundwater flow pathways that result from water pirated from mining and groundwater withdrawals, including from neighboring cities, counties and states, as well as from adjacent watersheds and across groundwater divides. Adverse impacts from this pirated water can result from induced saltwater intrusion and induced recharge, which dewaters wetlands and other surface waters (Bacchus, 2000; Bacchus et al., 2011; Krause \& Randolph, 1989; Lewelling, Tihansky, \& Kindinger, 1998; Metz \& Lewelling, 2009; Stewart \& Stedje, 1990; Watson, Stedje, Barcelo, \& Stewart, 1990). For example, although the 2013 DOAH case in Florida addressed numerous procedural inadequacies in the use of the Highlands Ranch Mitigation Bank in Clay County to justify the requested mitigation credits, it failed to address the adverse impacts that mitigation bank has experienced and will experience due to the initial DuPont Trail Ridge Mine and other existing and proposed mining, in Clay and Baker Counties due to fractures and other karst features in that area. Specifically, the hearing did not address how the applicant for the Highlands Ranch Mitigation Bank could provide reasonable assurance of compliance with requirements (a)-(f) of 373.4136(1) F.S. due to the existing and proposed mining in Clay County and surrounding counties. Similarly, the EIS analyses for the proposed expansion of phosphate mining in west-central Florida and the proposed Levy nuclear plant units in Levy County failed to consider the adverse impact on mitigation areas that will occur through fractures and other karst features in the vicinity of those proposed projects.

\subsection{Objectives, Hypotheses and Implications}

The first objective of this investigation was to select an appropriate area for the case study in rural counties in Florida. Baker and Clay Counties and the surrounding vicinity in northeast Florida met these criteria. These counties included areas where extensive mining had occurred in the recent past, significant expansion of mining was proposed and numerous mitigation banks and other conservation and environmentally sensitive lands occurred in proximity to existing and proposed mining areas. Baker and Clay Counties also represented areas where adverse environmental impacts from preferential groundwater flow described above, and more fully below, were not being evaluated or otherwise addressed. The second objective was to conduct a geospatial analysis of linear features throughout the study area using lineaments previously mapped by Vernon (1951) and the Florida Department of Transportation (FDOT, 1973) in analog format and georectified using established methods described by Lines et al. (2012). The geospatial analysis, using the ArcGISTM 10.1 geographic information system (GIS), included an evaluation of the frequency and distribution of these lineaments and previously reported sinkholes in proximity to existing and proposed mining, mitigation banks and other conservation and environmentally sensitive lands in the vicinity. The aim of this analysis was to describe the potential magnitude and extent of cumulative adverse environmental impacts from hydroperiod alterations and preferential groundwater flow pathways. Our alternative hypothesis, based on published literature described below, was that sinkholes would be associated with fractures and that fractures occur in the vicinity of the existing and proposed mining, mitigation banks and other conservation and environmentally sensitive lands. The theoretical and practical implications of this study were based on published literature described below and include identifying areas of potential adverse environmental impacts from preferential flow through fractures in the FAS that may occur many kilometers beyond the proposed project sites. These impacts and preferential flow are predicted to occur in response to groundwater extractions, excavations and other proposed actions that would alter natural hydroperiods and subsequently result in adverse impacts to wetlands and other surface waters, wildlife habitat and threatened and endangered species. Bacchus (2001) and Lines et al. (2012) provided examples of how adverse impacts result from hydroperiod alterations that constitute unpermitted taking of federally endangered and threatened species. The results of this study can be used as a primer to explain the crucial role of preferential groundwater flow pathways in predicting adverse environmental impacts and applied to other projects in the study area, with similar approaches applicable throughout Florida and the remaining FAS.

\section{The Study Area}

The study area, located in the peninsula of the regional Floridan aquifer system (FAS) in rural northeast Florida, U.S., includes Baker and Clay Counties and the surrounding vicinity. This area was selected because of the highly ranked wildlife habitat (Endries, Gilbert \& Kautz, 2009) and numerous mitigation banks and other conservation areas in proximity to extensive past mining and significant proposed expansion of mining. The initial DuPont Trail Ridge Mine and Florida Rock Vulcan Mine in Clay County and expanded DuPont Trail Ridge Mine in Baker County are examples of the most extensive existing mining in the study area. Figure 1A shows the location of Baker and Clay Counties and approximate extent of the FAS that is not submerged 
by the Gulf of Mexico and Atlantic Ocean. Figure 1B provides a more detailed view of the study area over an image accessed through the ESRI World Imagery service, showing locations of the proposed Old Castle mine, the initial and expanded DuPont Trail Ridge Mines (in Clay and Baker Counties respectively), the Florida Rock Vulcan Mine, mitigation banks and conservation lands. Mitigation banks identified by the St. Johns River Water Management District (SJRWMD) in the vicinity of the study area are provided in Table 1, with the mitigation bank adjacent to the initial DuPont Trail Ridge Mine in bold. A list of parks, state forests and other conservation areas in the study area vicinity are provided in Table 2, with the conservation areas in proximity to the initial DuPont Trail Ridge Mine in bold. The locations of these mitigation banks and conservation areas are shown in Figure 2, with identification numbers and letters included from Tables 1 and 2, respectively. The U.S. Department of Commerce Census Bureau's 2010 data indicate that the areas of Baker (http:/quickfacts.census.gov/qfd/states/12/12003.html) and Clay (http:/quickfacts.census.gov/qfd/states/12/12019.html) Counties, respectively, are 1515.73 square $\mathrm{km}(585.23 \mathrm{sq} \mathrm{mi})$ and $1565.28 \mathrm{sq} \mathrm{km}(604.36 \mathrm{sq} \mathrm{mi})$, with a population density of 18 people per sq $\mathrm{km}$ (46 people per sq mi) and 122 people per sq $\mathrm{km}$ (316 people per sq $\mathrm{mi}$ ).

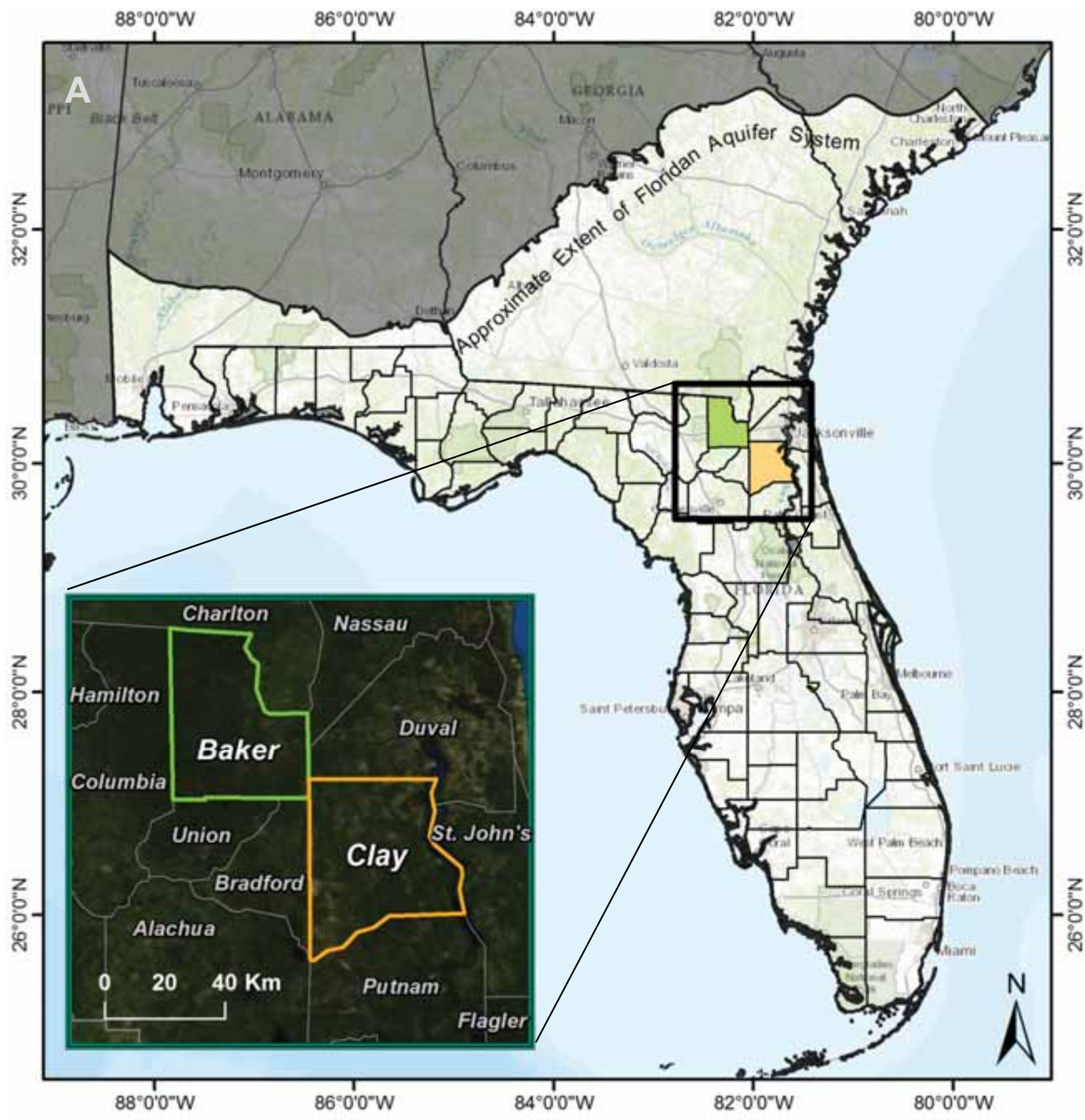




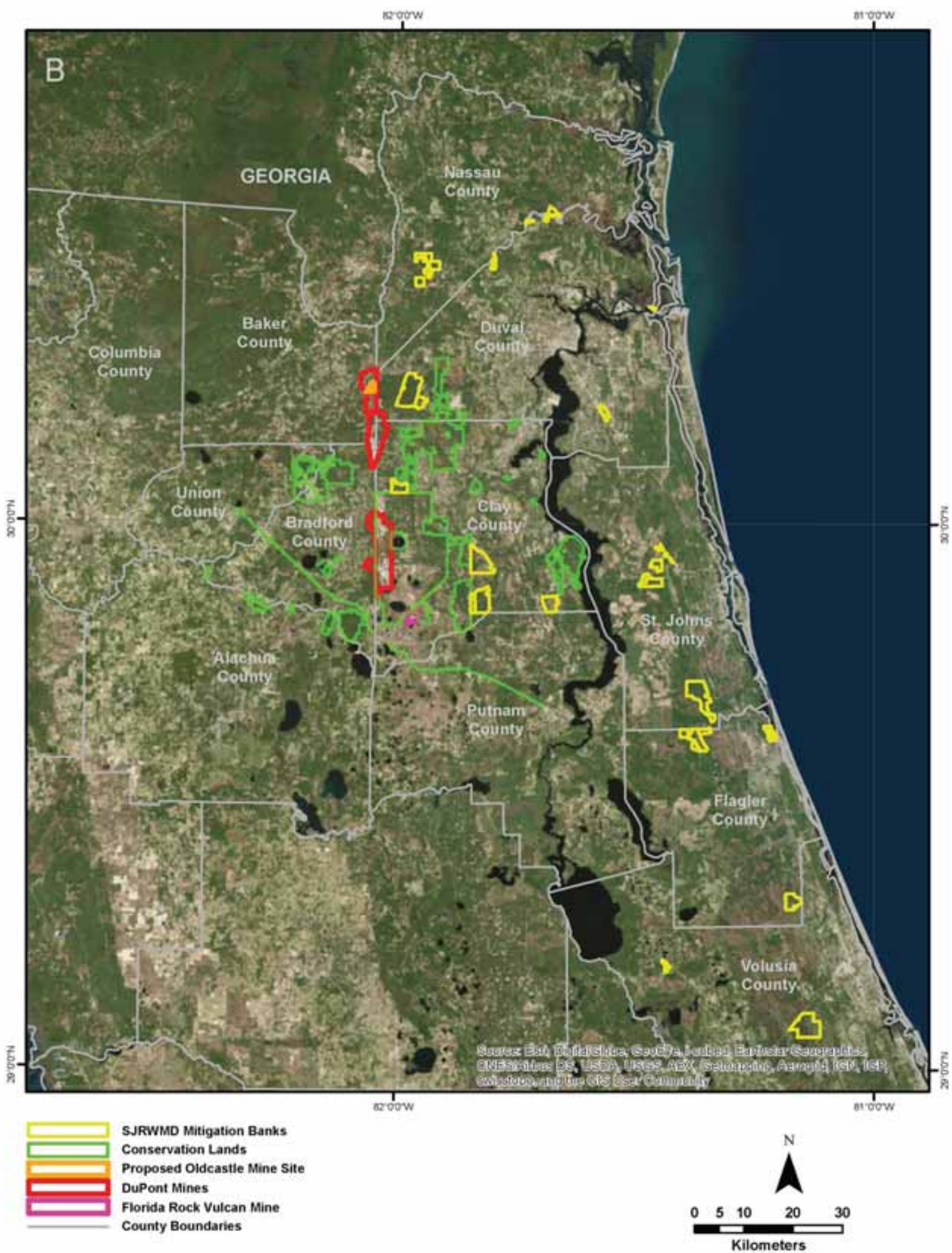

Figure 1.A. Location of Baker and Clay Counties in northeast Florida and approximate extent of the FAS not submerged by the Gulf of Mexico and Atlantic Ocean and

B. more detailed view showing locations of the proposed Old Castle mine, initial and expanded DuPont Trail Ridge Mines (Clay and Baker Counties respectively), Florida Rock Vulcan Mine, mitigation banks and conservation lands. 
Table 1. Mitigation banks identified by the St. Johns River Water Management District in the study area vicinity as of December 2013, with the mitigation bank adjacent to the initial DuPont Trail Ridge Mine shown in bold

\begin{tabular}{clcl}
\hline ID & \multicolumn{1}{c}{ Mitigation Bank } & ID & \multicolumn{1}{c}{ Mitigation Bank } \\
\hline 0 & Loblolly Mitigation Bank Pipeline & 22 & Lower St. Johns Mitigation Bank \\
1 & Brick Road Mitigation Bank & $23-24$ & Nochaway Mitigation Bank \\
2 & Lake Swamp Mitigation Bank & 25 & Colbert Cameron \\
3 & Northeast Florida Mitigation Bank & 26 & Northeast Florida Mitigation Bank \\
4 & North Florida Saltwater Marsh & 27 & Tupelo Mitigation Bank \\
5 & Sundew & 28 & Farmton North \\
6 & Loblolly Mitigation Preserve & 29 & Northeast Florida Mitigation Bank \\
7 & Tm Econ & $30-32$ & Barberville Mitigation Bank \\
8 & Mary A Ranch & 33 & Farmton Mitigation Bank-West Bank \\
9 & NEF2 Northeast Florida & 34 & Farmton Mitigation Bank-South Bank \\
$10-11$ & Longleaf Mitigation Bank & $35-36$ & NEFMB \\
12 & CGW & 37 & Thomas Creek/Three Rivers Mitigation Bank \\
$13-14$ & Lake Louisa \& Green Swamp & $38-41$ & Blackwater Creek \\
$15-16$ & FDOT Tosohatchee & 42 & Lake Monroe Mitigation Bank \\
17 & Longleaf Mitigation Pipeline & 43 & Fish Tail Swamp Mitigation Bank \\
18 & Longleaf Mitigation Bank & 44 & Port Orange Mitigation Bank \\
19 & Greens Creek Mitigation Bank & $\mathbf{4 5}$ & Highlands Mitigation Bank \\
20 & ECF-S East Central Fla. & 46 & Pellicer Flats \\
21 & Star 4 Mitigation Bank & 47 & Town Branch \\
\hline & & & \\
\hline
\end{tabular}

Table 2. Parks, state forests and other conservation areas in the study area vicinity as of December 2013, with conservation areas in proximity to the initial DuPont Trail Ridge Mine shown in bold.

\begin{tabular}{|c|c|c|c|}
\hline ID & Counties & Acres & Name \\
\hline A & Clay & 177 & Skinner-Smith Parcel \\
\hline $\mathrm{B}$ & Alachua & 975 & Monteocha Creek Conservation Easement \\
\hline $\mathbf{C}$ & Clay, Duval & 24,033 & Jennings State Forest \\
\hline $\mathbf{D}$ & Clay & 2,366 & Mike Roess Gold Head Branch State Park \\
\hline $\mathrm{E}$ & Clay & 260 & Moccasin Slough \\
\hline $\mathrm{F}$ & Bradford & 28 & Keystone Air Park Tract \\
\hline $\mathrm{G}$ & Clay, Duval & 386 & Branan Field Mitigation Park Wildlife and Environmental Area \\
\hline $\mathrm{H}$ & Clay, Duval & 5,366 & Cecil Field Conservation Corridor \\
\hline I & Alachua & 242 & Santa Fe River - AP\&E \\
\hline $\mathrm{J}$ & Clay & 150 & Camp Chowenwaw Park \\
\hline $\mathrm{K}$ & Clay & 2,683 & Longbranch Crossing Conservation Easement \\
\hline $\mathrm{L}$ & Clay & 964 & Black Creek Ravines Conservation Area \\
\hline M & Clay & 10,388 & Bayard Conservation Area \\
\hline $\mathbf{N}$ & Clay & 73,076 & Camp Blanding Military Reservation \\
\hline $\mathrm{O}$ & Clay & 900 & Arahatchee Conservation Easement \\
\hline $\mathrm{P}$ & Bradford & 138 & Edwards Bottomland \\
\hline $\mathrm{Q}$ & Clay & 408 & Crosby Sanctuary \\
\hline $\mathrm{R}$ & Clay & 12,262 & Belmore State Forest \\
\hline $\mathrm{S}$ & Bradford, Union & 16,200 & Raiford Wildlife Management Area \\
\hline $\mathrm{T}$ & Bradford, Clay, Putnam Union & 613 & Palatka-to-Lake Butler State Trail \\
\hline $\mathrm{U}$ & Brad & 1,468 & Graham Conservation Area \\
\hline $\mathrm{V}$ & Brad & 167 & New River Conservation Easement \\
\hline $\mathrm{W}$ & Alachua, Bradford & 7,368 & Santa Fe Swamp Conservation Area \\
\hline $\mathrm{X}$ & Clay & 1,166 & 301 Land Investments Parcels \\
\hline
\end{tabular}




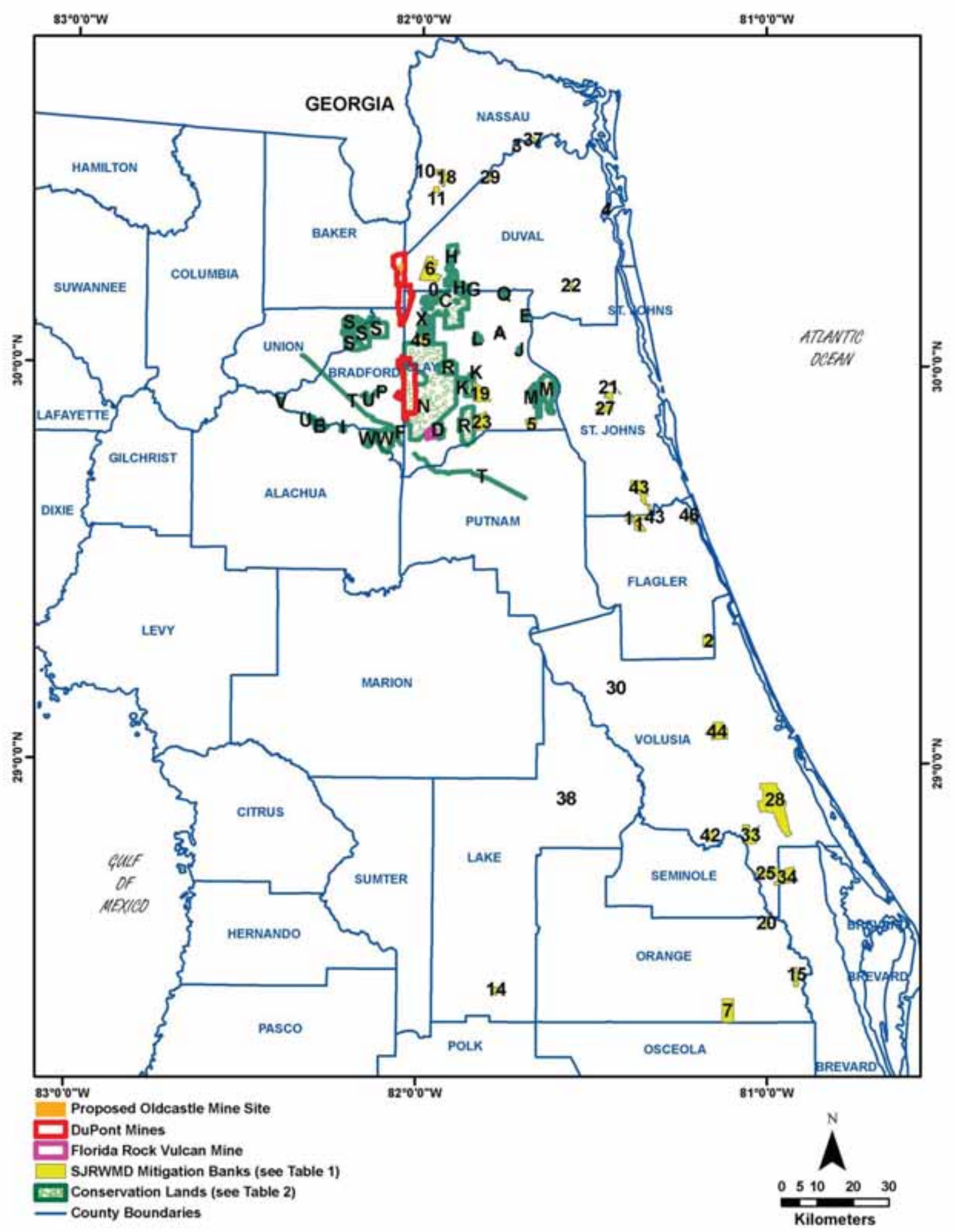

Figure 2. Mitigation banks and conservation areas in the St. Johns River Water Management District boundaries

\section{Data and Methods}

\subsection{Digital Data and Georectification}

Lineaments previously mapped in analog format by Vernon (1951) and FDOT (1973) in our northeast study area and 
georectified using established methods described by Lines et al. (2012) were superimposed over various base maps for this analysis and to create the figures and tables provided below. Base maps included: (1) satellite images accessed through the ESRI World Imagery service and the Microsoft BING Maps service; (2) the raster file for the Integrated Wildlife Habitat Ranking System's ranked habitat developed for the Florida Fish and Wildlife Conservation Commission (FFWCC) in 2009 (Endries, Gilbert, \& Kautz, 2009); and (3) the extent of wetlands in the analysis and figures described below, obtained from the U.S. Fish and Wildlife Service (USFWS) National Wetlands Inventory (NWI). The file for the state-ranked habitat was obtained from http://myfwc.com/research/gis/data-maps/terrestrial/wildlife-habitat-ranking-system/. The NWI data were obtained from http://www.fws.gov/wetlands/Data/State-Downloads.html.

Coordinates for modern sinkholes obtained from the database at the University of South Florida (http://fit.usf.edu/florida/maps/galleries/sinkholes/), based on data gathered by the Florida Geological Survey (FGS) and the Florida Department of Environmental Protection (FDEP), were used to depict the locations of those sinkholes in our case study. Shapefiles from the SJRWMD provided the locations of the proposed and existing mines, groundwater supply wells authorized by SJRWMD consumptive use permits (CUPs), and mitigation banks. The locations of other conservation areas, such as those in the Camp Blanding Military Reservation that subsequently were mined by the initial DuPont Trail Ridge Mine in Clay County, were provided as shapefiles from the Florida Natural Areas Inventory (FNAI) and SJRWMD databases.

\subsection{Sampling and Analysis Procedures}

The study area includes linear features indicative of fractures (including faults) that were mapped previously. Rose diagrams similar to those generated by Norman (1976), Harnett and Barnett (1977) and Brook and Allison (1983) were created for spatial frequency analysis of lineaments. The angle distribution of linear features was analyzed over the study area for all geometrically rectified and vectorized lineaments mapped by Vernon (1951) and FDOT (1973) included in or extending to Baker and Clay Counties. A multi-cell grid covering the area of study was used with these selected lineaments for characterization of directional distribution for cumulative lengths of linear features over the region, as described in Lines et al. (2012). For each grid cell (cell size $=0.12^{\circ} \times 0.12^{\circ}$, the entire length of vectorized lineaments within or entering the cell was measured and the cumulative length of lineaments for individual $15^{\circ}$ azimuth steps $\left(\right.$ north $=0^{\circ}$ ) was calculated and graphed. The angular distribution of cumulative lengths also was computed within Baker and Clay County boundaries. Rose diagrams were created based on descriptions of length-weighted rose diagrams provided by Prost (2002). Length-weighted rose diagrams were not based on lineaments clipped to cells or county boundaries because the objective was to show potential groundwater connectivity and total lineament length. Instead, total lengths were calculated including the parts of lineaments that extend beyond the two-county study area.

Geographic Information Science (GISci) has been established for visualization and mapping of rock properties in regions with subtle topography (Belt \& Paxton, 2005). ArcGIS Version 10.1 was used for the geospatial analysis of lineaments and sinkholes in the study area. All data layers, such as lineaments, sinkholes and county boundaries, were projected to a common, Robinson projection system, which has pseudocylindrical projection and minimal distortions within areas approximately $45^{\circ}$ north and south of the equator. Our northeast Florida study area is located between $29^{\circ} \mathrm{N}$ and $30^{\circ} 37^{\prime} \mathrm{N}$ latitude. This projection system is known as a compromise projection that maintains all types of distortions at relatively low levels over most of the globe (Usery, Finn, \& Mugnier, 2009; Dean, 2012). Lineament segments with minor distortions that were unable to be digitized as a straight line were adjusted using the "Straight Segment" tool of the ArcGIS "Editor" and "Advanced Editing." After these preprocessing steps were completed, the geospatial analysis was conducted. The numbers of intersection points for all lineaments in Baker and Clay counties were calculated using the ArcGIS "Intersect" tool, choosing "Output Type" as "POINT". Then, the lengths of all lineaments were calculated using ArcGIS "Calculate Geometry" in the attribute table. The shortest distance from each sinkhole to the nearest lineament was calculated using the ArcGIS "Near" tool, which determines the distance from each input feature to the nearest identified feature within a search radius.

\section{Results}

\subsection{Proximity of Fractures to Existing and Proposed Mines, Mitigation Banks and Other Environmentally Sensitive Areas}

Figure 3 shows a GIS overlay of the extent of fractures mapped as lineaments by Vernon (1951, as black diagonal lines) and by the FDOT (1973, as red diagonal lines) in proximity to the proposed Old Castle Mine, the existing DuPont Trail Ridge Mine and Florida Rock Vulcan Mine, mitigation banks and parks, state forests and other conservation areas in the study area. 




Figure 3. Locations of previously reported fractures (red and black diagonal lines), in proximity to the proposed Old Castle Mine, initial and expanded DuPont Trail Ridge Mines, Florida Rock Vulcan Mine, mitigation banks and parks, state forests and other conservation areas in the northeast Florida study area 
- red) based on the Integrated Wildlife Habitat Ranking System developed under the Florida Fish and Wildlife Conservation Commission (FFWCC) in 2009 (Endries, Gilbert, \& Kautz, 2009). Overlying the state-ranked integrated wildlife habitat are the same fractures, parks, state forests and other conservation areas described in the previous figure. Figure 4A depicts the fractures mapped by Vernon (1951) as black diagonal lines and the fractures mapped by FDOT (1973) as red diagonal lines, with the white areas in the northeast Florida study area representing waterbodies (e.g., the St. Johns River and natural lakes). Figure 4B is an enlargement of the Clay County vicinity, the initial DuPont Trail Ridge Mine and groundwater supply (CUP) wells for that mine and the Florida Rock Vulcan Mine. The NWI wetlands (dark blue) are included over the state-ranked integrated wildlife habitat base map. Also included are the three modern sinkholes located in Clay County (light blue circles identified with large, bold A, B and C), south of the DuPont Trail Ridge Mine. Also represented in Figure 4B are the Conservation Lands with the same alpha codes provided in Table 2 shown in Figures 2 and 3 in small letters. Figure $4 \mathrm{C}$ is an enlargement of the Baker County vicinity, the proposed Old Castle mine site, DuPont Mine expansion and municipal groundwater supply (CUP) wells for Macclenny and Glen St. Mary. The NWI wetlands (dark blue) also are included in this figure over the state-ranked integrated wildlife habitat base map.

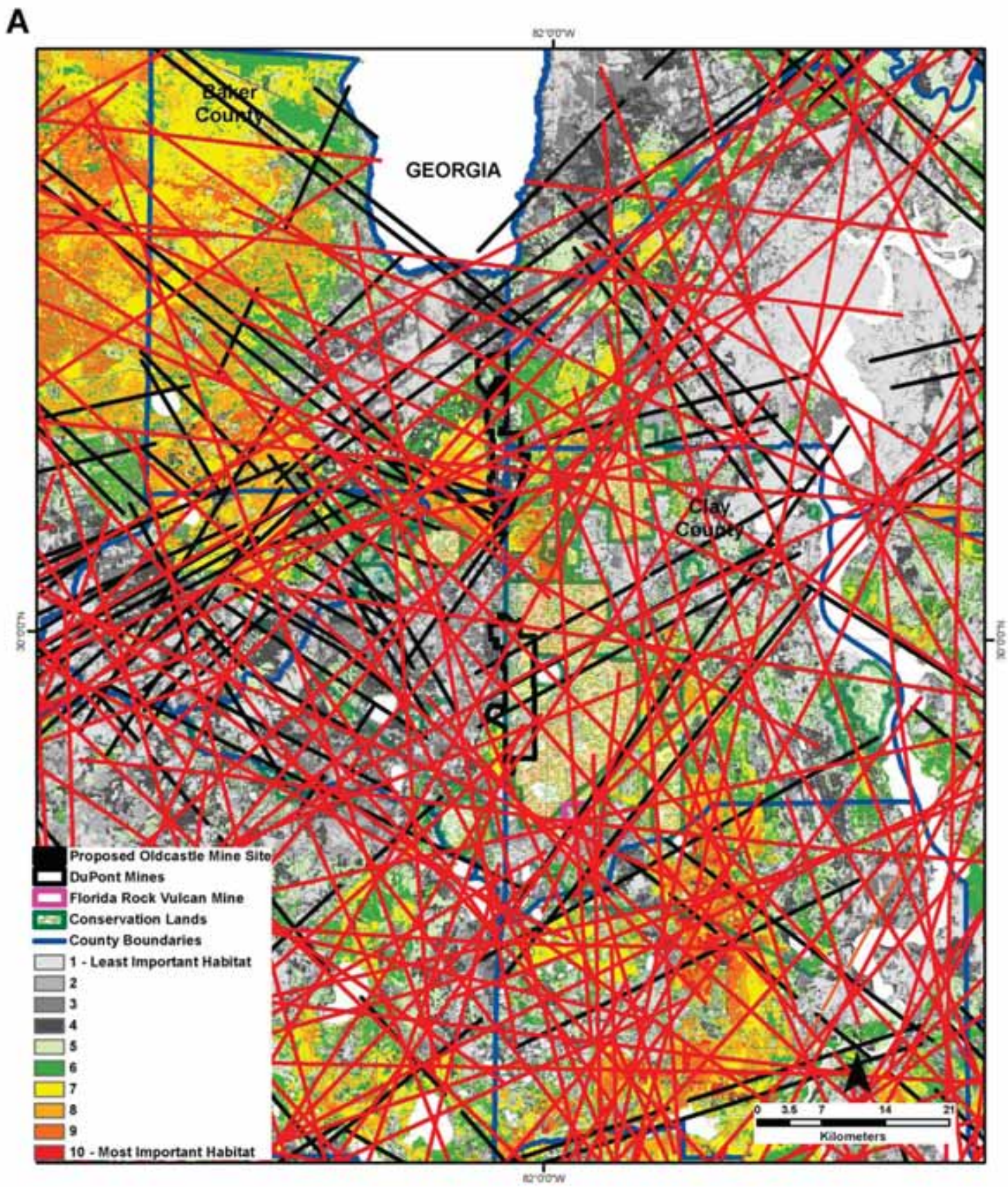




\section{B}

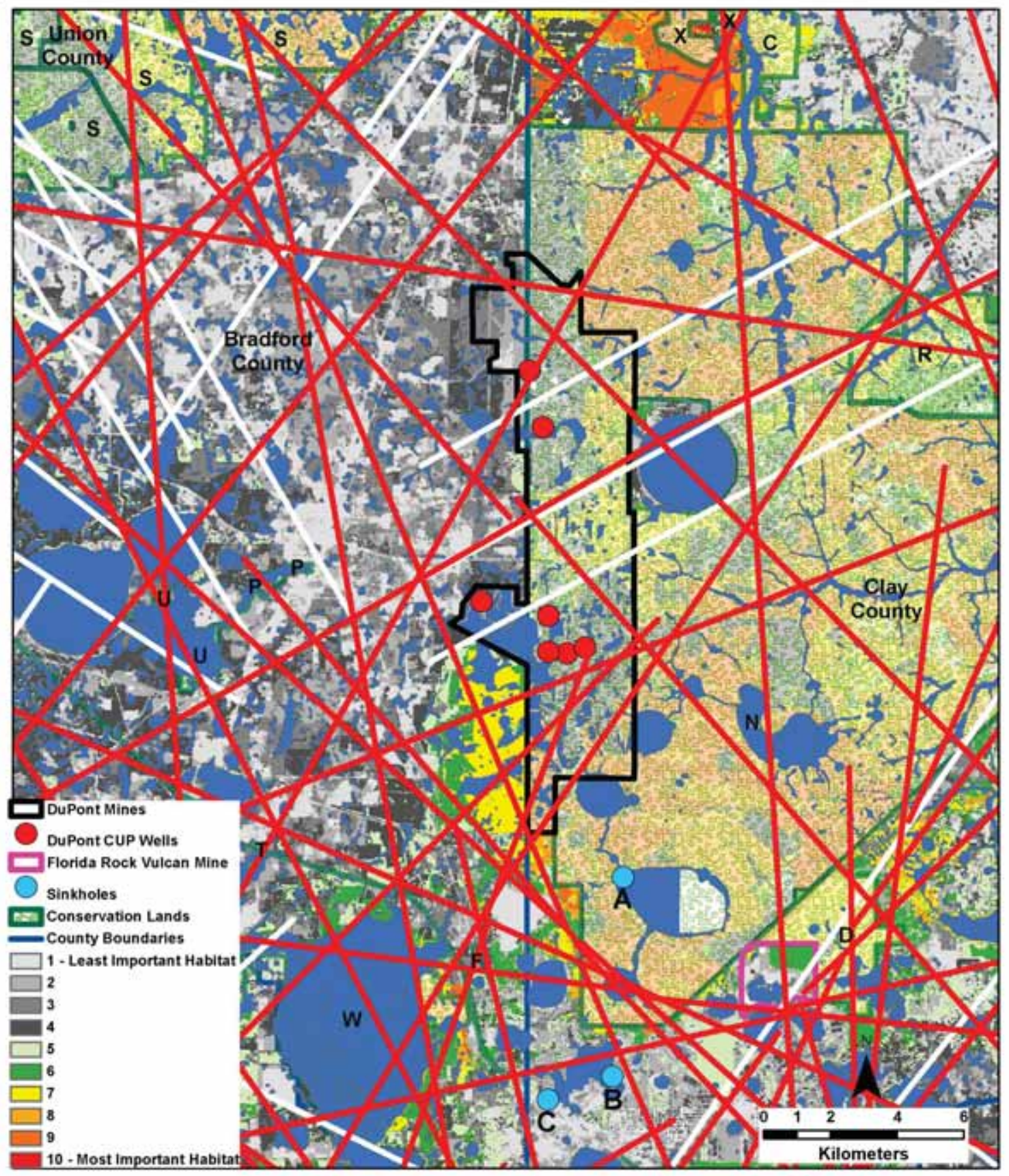




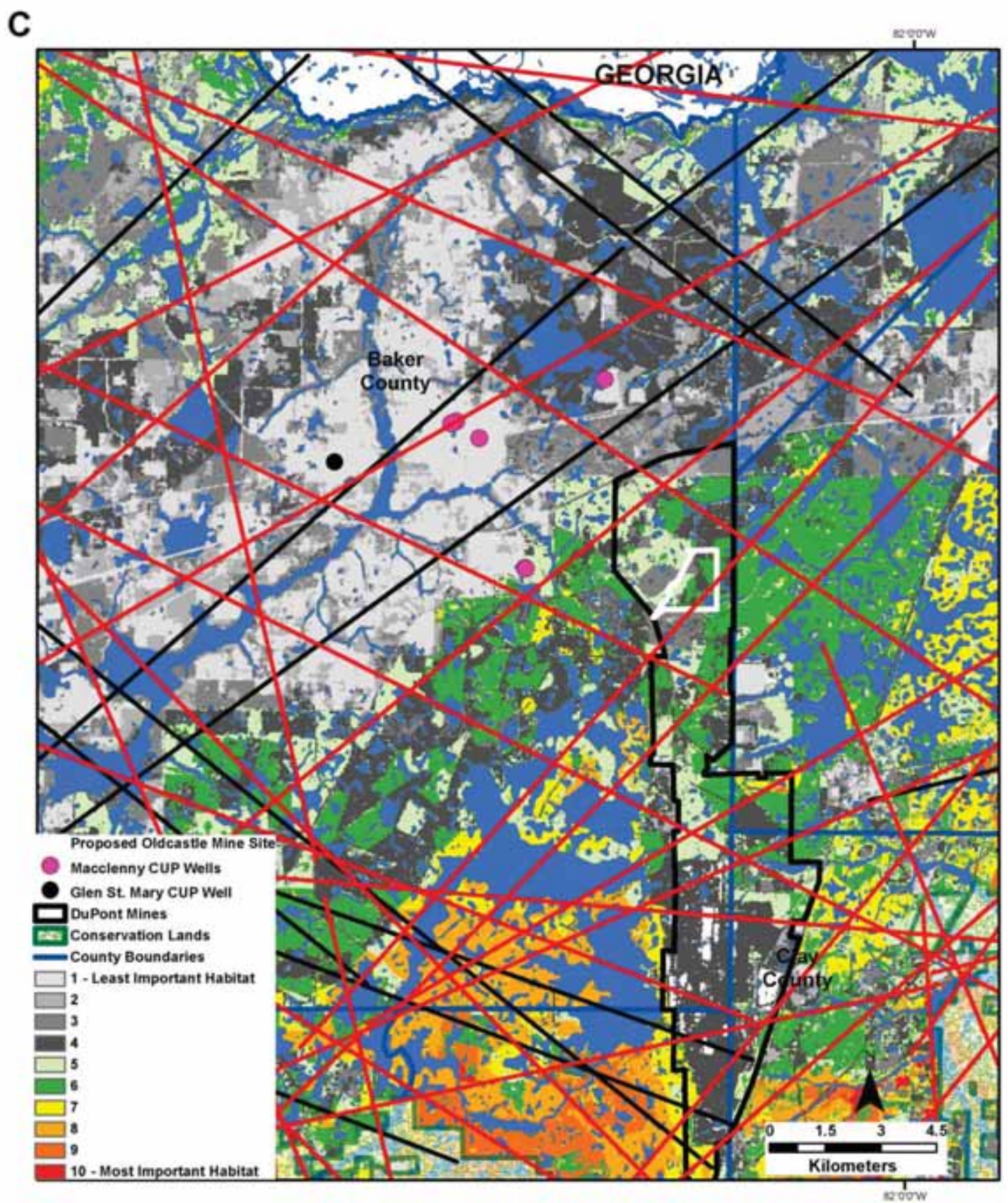

Figure 4. A. Locations of fractures (diagonal lines), existing DuPont Trail Ridge Mine and proposed Old Castle mine site, over state-ranked integrated wildlife habitat map in study area;

B. Enlargement of the Clay County vicinity, mines, supply wells and sinkholes, with NWI wetlands;

C. Enlargement of the Baker County vicinity, proposed and existing mines and municipal supply wells, with NWI wetlands

The base map for Figure 5 is the extent of NWI wetlands in the study area, in blue and grey. The grey areas represent wetlands at a scale that is too small in Figure 5 to be shown in blue. Overlying the NWI wetlands are the same fractures, mines and proposed mine site described in previous figures. 


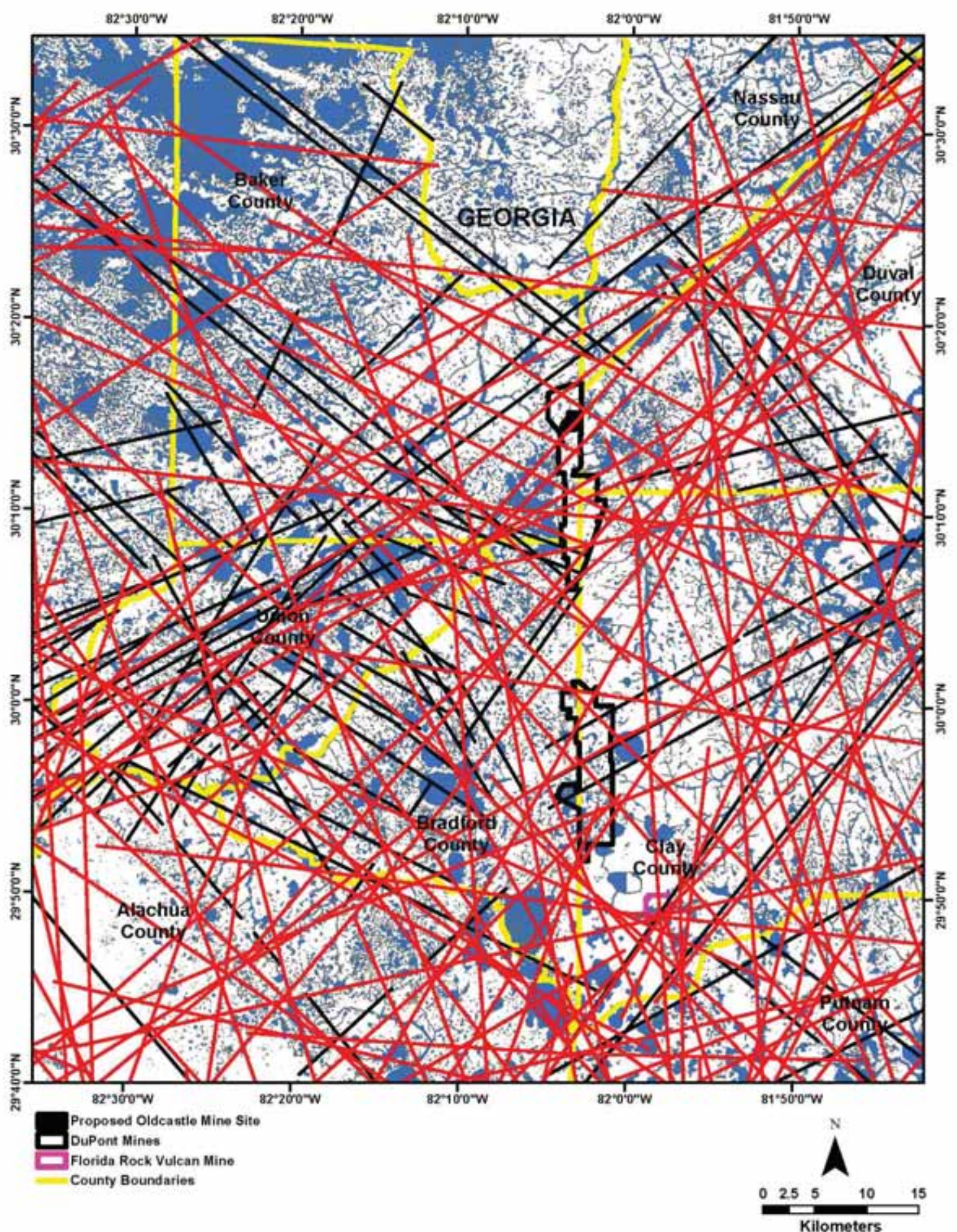

Figure 5. Locations of previously reported fractures (red and black diagonal lines), over NWI wetlands (blue and grey shading), in proximity to existing mines and the proposed Old Castle Mine site

\subsection{Analyses of Fractures and Modern Sinkholes}

The length-weighted results for distribution density analyses of fractures mapped by Vernon (1951) and FDOT (1973) are shown in Figures $6 \mathrm{~A}$ and $\mathrm{B}$ as $0.12^{\circ} \times 0.12^{\circ}$ multi-cell rose diagrams for the study area, including the area of existing and proposed mines in Baker and Clay Counties and environmentally sensitive areas in the vicinity. Diagram petals for the multi-cell grids indicate distance in kilometers, ranging from 0 to $250 \mathrm{~km}$ (0 to $155 \mathrm{mi})$ for Vernon $(1951$, center $=0 \mathrm{~km}$, outer circle $=250 \mathrm{~km}$, 
step $=50 \mathrm{~km})$ and from 0 to $800 \mathrm{~km}(0$ to $497 \mathrm{mi})$ for FDOT $(1973$, center $=0 \mathrm{~km}$, outer circle $=800 \mathrm{~km}$, step $=100 \mathrm{~km})$ from the center of the diagram to the outer circle, respectively.

Results for the length-weighted distribution density rose diagram analyses of fractures, mapped for the Baker County area, by Vernon (1951) and FDOT (1973), and Clay County area, by Vernon (1951) and FDOT (1973), respectively, are shown in Figures 7A through D. Diagram petals in Figure 7 indicate distance in kilometers, ranging from 0 to $300 \mathrm{~km}(0$ to $186 \mathrm{mi})$ for Vernon (1951) and 0 to $1400 \mathrm{~km}$ (0 to $870 \mathrm{mi}$ ) for FDOT (1973) from the center of the diagram to the outer circle, respectively. The length step is $50 \mathrm{~km}$ (31 mi) for Vernon (1951) and $200 \mathrm{~km}$ (124 mi) for FDOT (1973). The frequency of fracture intersections, longest and shortest fractures, and mean fracture lengths for Baker and Clay Counties, Florida are summarized in Table 3. The number and lengths of fractures mapped by Vernon (1951) and by FDOT (1973) in Baker County and Clay County, respectively, are shown in Figures 8A and B. The state's sinkhole database at the University of South Florida that includes only modern sinkholes mapped through 2008, reports no sinkholes located in Baker County and only three sinkholes located in Clay County. Table 4 provides the distances from those three sinkholes to the nearest fracture and nearest intersection of fractures (in km) mapped by Vernon (1951) and by FDOT (1973). Figure 4B shows the proximity of those three sinkholes (identified as A, B and C) to the nearest fracture and nearest intersection of fractures mapped by Vernon (1951, white diagonal lines), and by FDOT (1973, red diagonal lines).

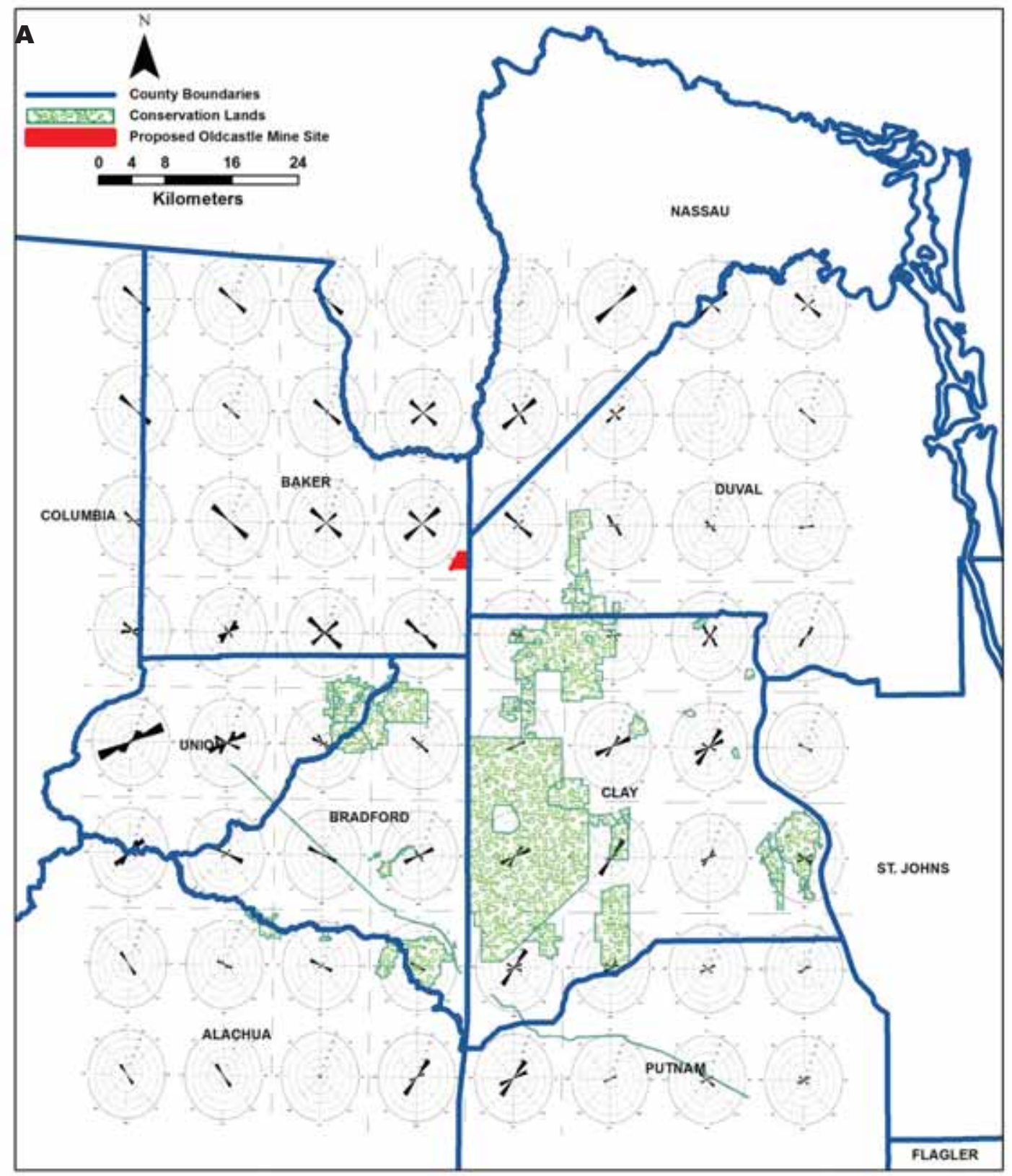




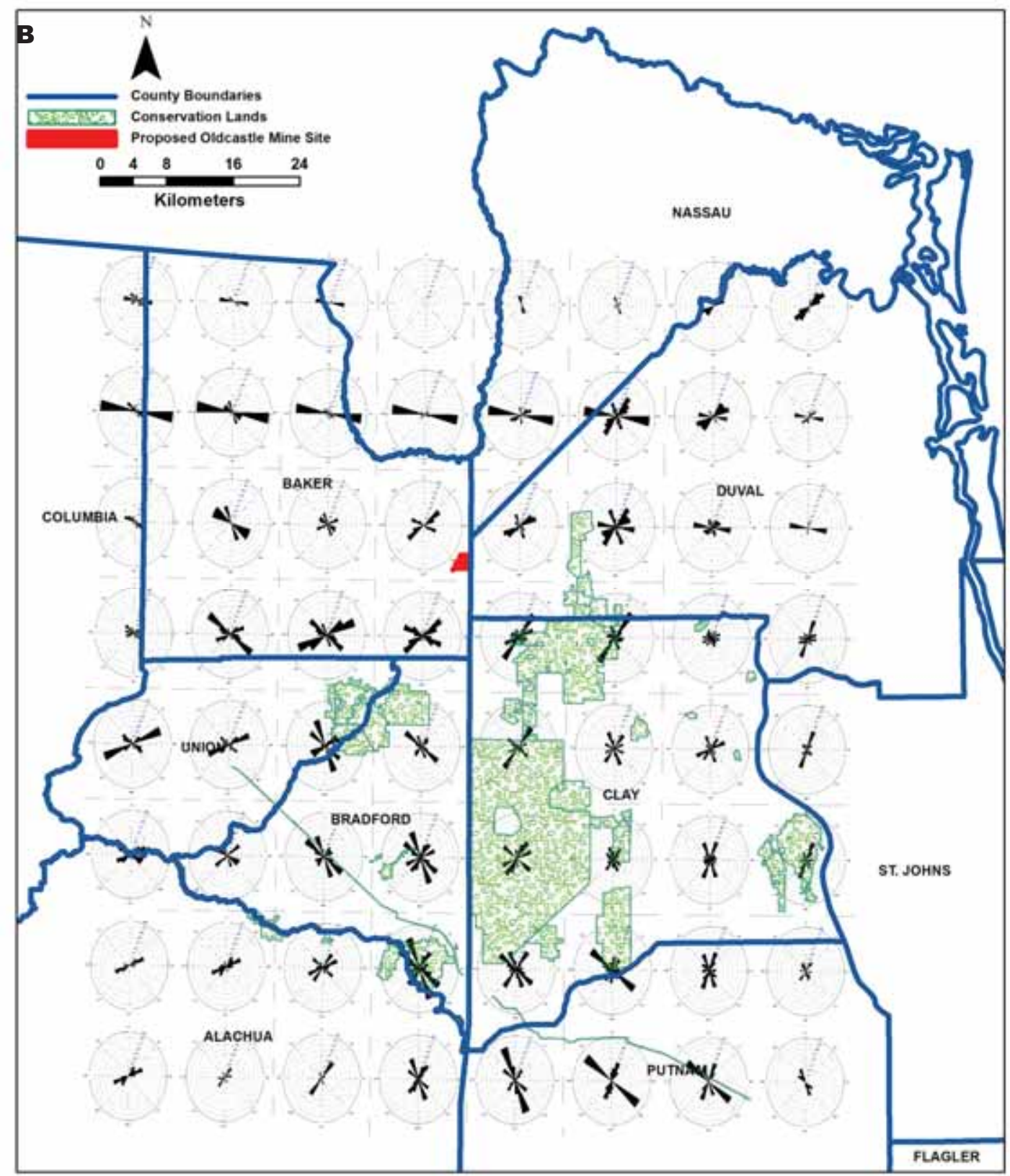

Figure 6. Length-weighted rose diagrams showing distribution density in $0.12^{\circ} \times 0.12^{\circ}$ grid cells. throughout the study area for fractures mapped by:

A. Vernon (1951, radii $=0$ to $250 \mathrm{~km}$ ) and B. FDOT (1973, radii $=0$ to $800 \mathrm{~km})$ 

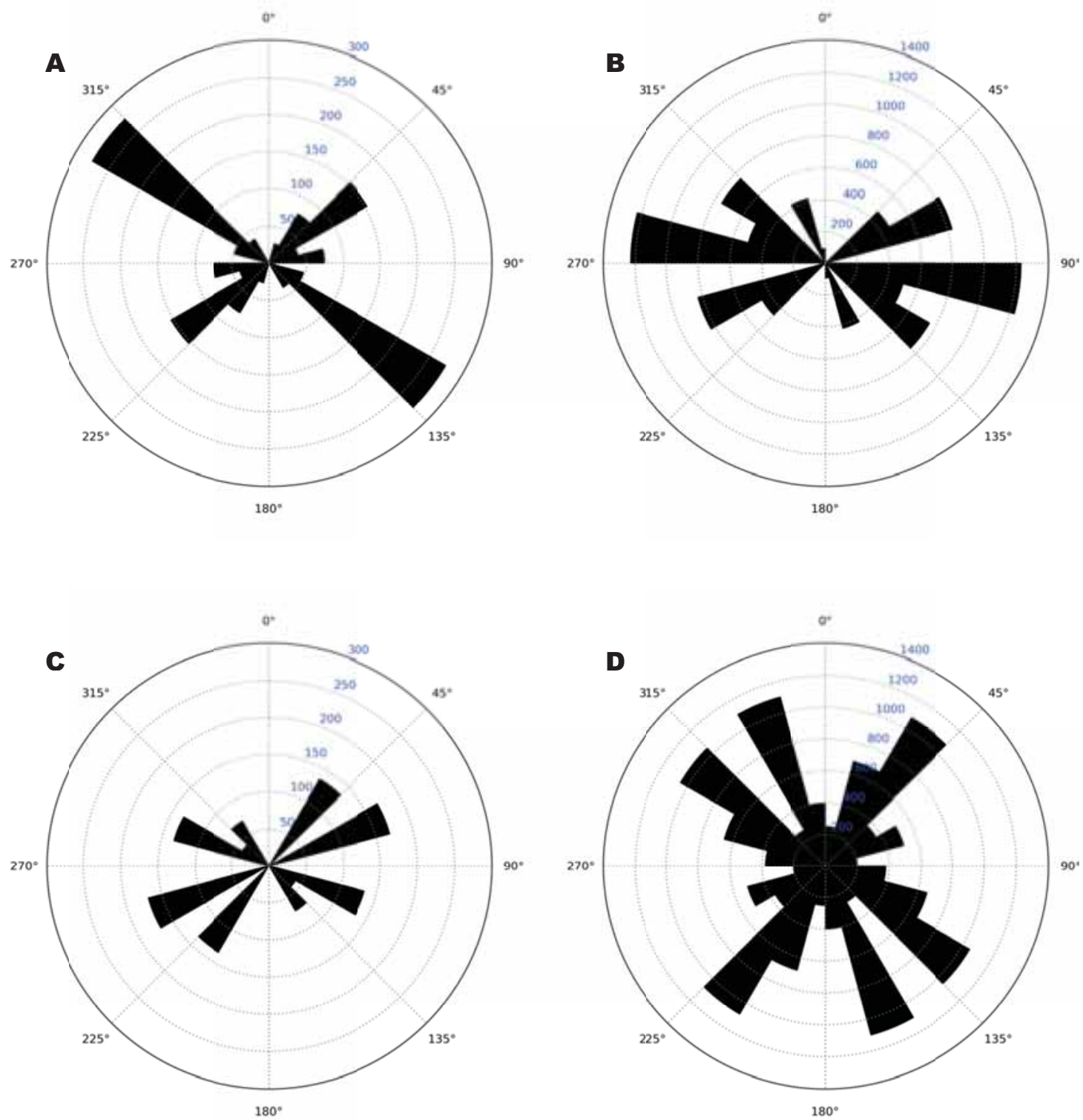

Figure 7. Length-weighted rose diagrams showing distribution density for fractures throughout the study area, mapped by:

A. Vernon (1951, radius $=0$ to $300 \mathrm{~km}$ ) in Baker County; B. FDOT (1973, radius $=0$ to 1,400 km) in Baker County;

C. Vernon (1951, radius $=0$ to $300 \mathrm{~km}$ ) in Clay County and D. FDOT (1973 radius $=0$ to $1,400 \mathrm{~km}$ ) in Clay County

Table 3. Frequency of fracture intersections, longest and shortest fractures and mean fracture lengths for Baker and Clay Counties, Florida.

\begin{tabular}{|c|c|c|c|c|c|c|c|c|}
\hline \multirow[t]{2}{*}{ County } & \multirow{2}{*}{$\begin{array}{c}\text { Fracture } \\
\text { Intersections }\end{array}$} & \multicolumn{2}{|c|}{$\begin{array}{c}\text { Total } \\
\text { Fractures }\end{array}$} & \multirow{2}{*}{$\begin{array}{c}\text { Total } \\
\text { Combined } \\
\text { Fractures } \\
\end{array}$} & \multicolumn{2}{|c|}{$\begin{array}{l}\text { Shortest-Longest } \\
\text { Fractures (km) }\end{array}$} & \multicolumn{2}{|c|}{$\begin{array}{l}\text { Mean Fracture } \\
\text { Lengths (km) }\end{array}$} \\
\hline & & Vernon & FDOT & & Vernon & FDOT & Vernon & FDOT \\
\hline Baker & 220 & 24 & 29 & 53 & $7 / 75$ & $58 / 358$ & 28.690 & 139.34 \\
\hline Clay & 610 & 15 & 56 & 71 & $13 / 73$ & $21 / 363$ & 35.269 & 123.23 \\
\hline
\end{tabular}



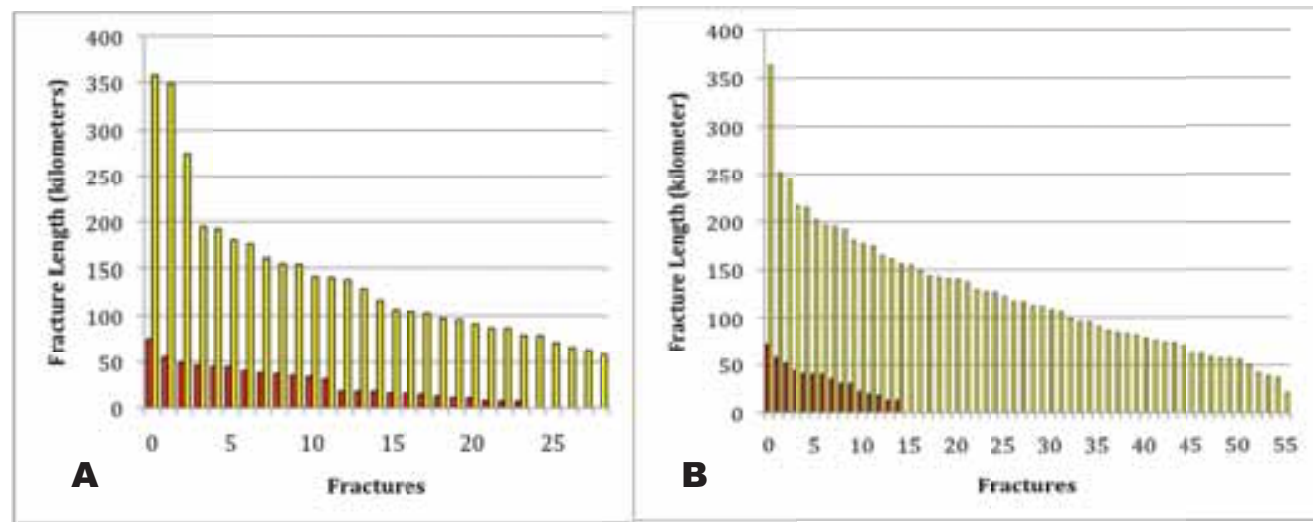

Figure 8. Fracture length mapped from aerial photographs (Vernon, 1951, red bars) and from satellite images (FDOT, 1973, yellow bars) in: A. Baker County, Florida and B. Clay County, Florida

Table 4. Distances from sinkholes in Clay County, Florida to the nearest fracture and nearest intersection of fractures mapped by Vernon (1951) and FDOT (1973)

\begin{tabular}{|c|c|c|c|c|c|}
\hline \multirow{2}{*}{$\begin{array}{l}\text { Sinkhole } \\
\text { ID }\end{array}$} & \multirow{2}{*}{$\begin{array}{c}\text { State } \\
\text { Sinkhole } \\
\text { Number }\end{array}$} & \multicolumn{2}{|c|}{$\begin{array}{c}\text { Shortest Distance to } \\
\text { Fracture (km) }\end{array}$} & \multicolumn{2}{|c|}{$\begin{array}{c}\text { Shortest Distance to } \\
\text { Fracture Intersection (km) }\end{array}$} \\
\hline & & Vernon & FDOT & Vernon & FDOT \\
\hline A & 2403 & 5.28 & 2.17 & 14.61 & 2.42 \\
\hline B & 2404 & 2.59 & 0.39 & 8.78 & 0.73 \\
\hline C & 2405 & 3.61 & 0.78 & 8.34 & 1.04 \\
\hline
\end{tabular}

\section{Discussion}

\subsection{Spatial Density and Distribution of Fractures, Fracture Intersections and Lengths}

Figures 3, 4, and 5 illustrate the extensively fractured nature of the bedrock in the northeast Florida study area. Baker and Clay Counties alone have a total of 830 fracture intersections (Table 3), which are potential locations of interlinked cavities where changes in ground water may be magnified. Groundwater alterations include changes in water quality and hydroperiods, not just water levels. The fact that two of the municipal supply wells for Macclenny (Figure 4C) are aligned along a fracture that intersects with other fractures, including one that intersects the site of the proposed Old Castle mining site, should have been a focal point of the potential adverse impacts on water quality and water quantity from that proposed mine.

Harnett and Barnett (1978) showed that rose diagrams can reveal fracture trends in a buried bedrock surface that are visible only sporadically through overlying structures. Norman (1976) provided a more detailed description of the relevance of rose diagrams. Figure 6 illustrates the distribution density of fractures, mapped by Vernon (1951) using aerial photographs and those mapped by FDOT (1973) using satellite imagery as $0.12^{\circ} \times 0.12^{\circ}$ length-weighted rose diagram grid cells throughout vicinity of Baker and Clay Counties. Figure 7A-D provides a comparison of the differences in direction and frequency of those same fractures, for Baker and Clay Counties. Results in this study differ for lineaments indicative of fractures mapped by Vernon (1951) using aerial photographs and those mapped by FDOT (1973) using satellite imagery. Those differences are consistent with results from other studies using either aerial photographs or satellite images (Norman, 1976). The differences are presumed to be due to the regional fractures that are longer and more apparent in satellite imagery (Littlefield, Culbreath, Upchurch, \& Stewart, 1984; Norman, 1976). Those differences are evident in the bar graphs of Figure 8, which show considerably longer fractures mapped using satellite images in both counties. Mean fracture lengths also reflected that pattern (Table 3). The longest fractures mapped in those two counties using aerial photographs was approximately $75 \mathrm{~km}$, while the longest fractures mapped using satellite images was approximately $360 \mathrm{~km}$ (Figure 8). The number of fractures mapped using aerial photographs and satellite images was approximately the same for Baker County (24 and 29, respectively), while more than three times as many fractures were identified in Clay County using satellite images (Table 3 and Figure 8). Figures 3, 4, and 5 also show that different fractures were mapped, based on aerial photographs and satellite images.

Adverse environmental impacts in the Highlands Mitigation Bank, Jennings State Forest and other conservation areas should have been considered prior to authorization of the mines and establishment of that mitigation bank. This conclusion is based on the fact that the fractures dissecting the DuPont Trail Ridge Mine groundwater supply wells and mines also extend through that mitigation bank, state forest and numerous other conservation areas. Krause and Randolph (1989) emphasized that fractures and 
other karst conduits that are pathways of preferential groundwater flow are not constrained by governmental boundaries such as county and state boundaries.

In an attempt to evaluate areas that could be more susceptible to experiencing adverse environmental impacts from mining and other groundwater alterations, such as those described by Bacchus (2006) and Bacchus et al. (2003), ground reconnaissance was conducted for this study prior to the georectification of features mapped as lineaments in the study area and the mapping of modern sinkholes in the study area from the state's sinkhole database. Some of the procedural steps recommended by Ogden (1984) for sinkhole analysis also were used as guidance in selecting areas for ground reconnaissance for adverse environmental impacts in the vicinity of the mine sites. Figure 9 shows the numbered Global Positioning System (GPS) locations of some of those areas of ground reconnaissance that were identified using U.S. Geological Survey (USGS) topographic maps and established hydroecological indicators of groundwater alterations, such as those described by Bacchus et al. (2003), and knowledge from other sites in Florida where adverse environmental impacts occurred from mining and other groundwater alterations. In all cases, adverse environmental impacts were identified at the ground reconnaissance locations where greater susceptibility was predicted. The locations of modern sinkholes are shown in Figure 9 as light blue circles, identified by large, bold A, B and C, south of the initial DuPont Trail Ridge Mine. Also included in Figure 9 are the same Conservation Lands shown in Figures 2 and 3, identified in small letters corresponding to the alpha codes provided in Table 2. Note the proximity of the numbered GPS locations to the locations of fractures mapped by Vernon (1951) and FDOT (1973). In some cases, the observed areas of adverse impacts were not accessible and a nearby location was marked using the GPS. Examples of those cases include GPS locations that are located at greater distances from the mapped fractures. Some GPS points of adverse environmental impacts were located at a considerable distance from a mapped fracture, but in the vicinity of relict sinkholes that represent natural lakes in the area, suggesting that additional fractures occur in those areas that were not mapped by Vernon (1951) or FDOT (1973). 


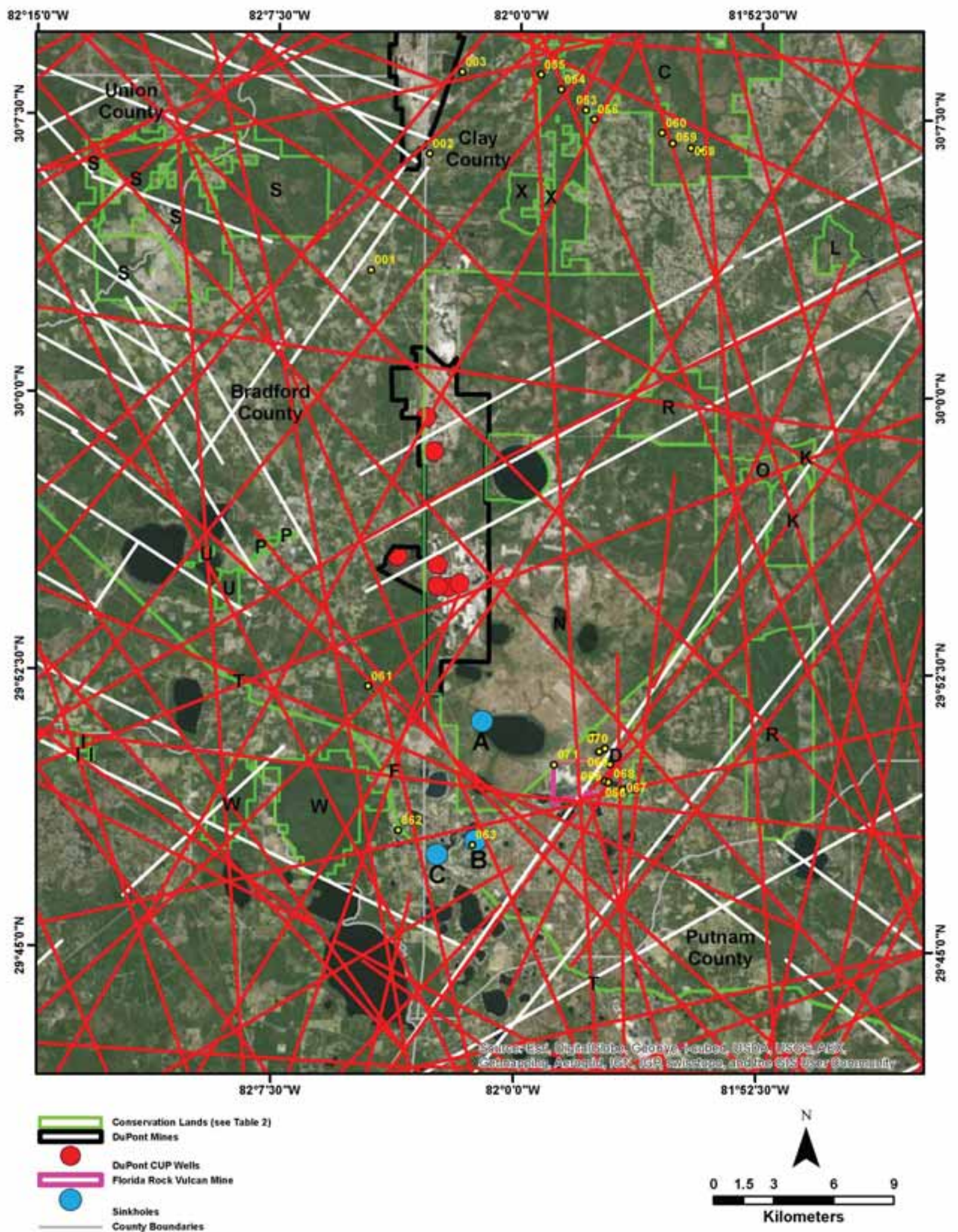

Figure 9. Examples of locations where ground reconnaissance was conducted (yellow circles) prior to creation of georectified maps for the study area of fractures by Vernon (1951, white diagonal lines) and FDOT (1973, red diagonal lines) and prior to the mapping of modern sinkholes from the state's database

Figures 10, 11 and 12, provide examples of the adverse environmental impacts identified during the ground reconnaissance in 
Gold Head Branch State Park, Clay County lakes with privately owned lake-front property and Jennings State Forest, respectively. Figure 10A shows one of the smaller natural sinkhole lakes in the state park, with the tree line representing the approximate historic water level. Figure 10B is an enlargement of "NO SWIMMING" sign from Figure 10A in the foreground and extensive dewatered lake bed in the back ground. In the foreground of Figure 10C, the state park sign depicts the historic water level of Johnson Lake, located approximately at the tree line. The dewatered lake bottom and tree line are shown in the background of Figure 10C. The boat launch referenced in the Johnson Lake sign is shown in the foreground of Figure 10D, with the dry lake bed and tree line approximating the historic water level of Johnson Lake sign in the background. Figure 10E provides a more extensive view of the dry lake bed in foreground behind Johnson Lake sign and a small area of remaining water in the distant background, with the extension of the tree line.

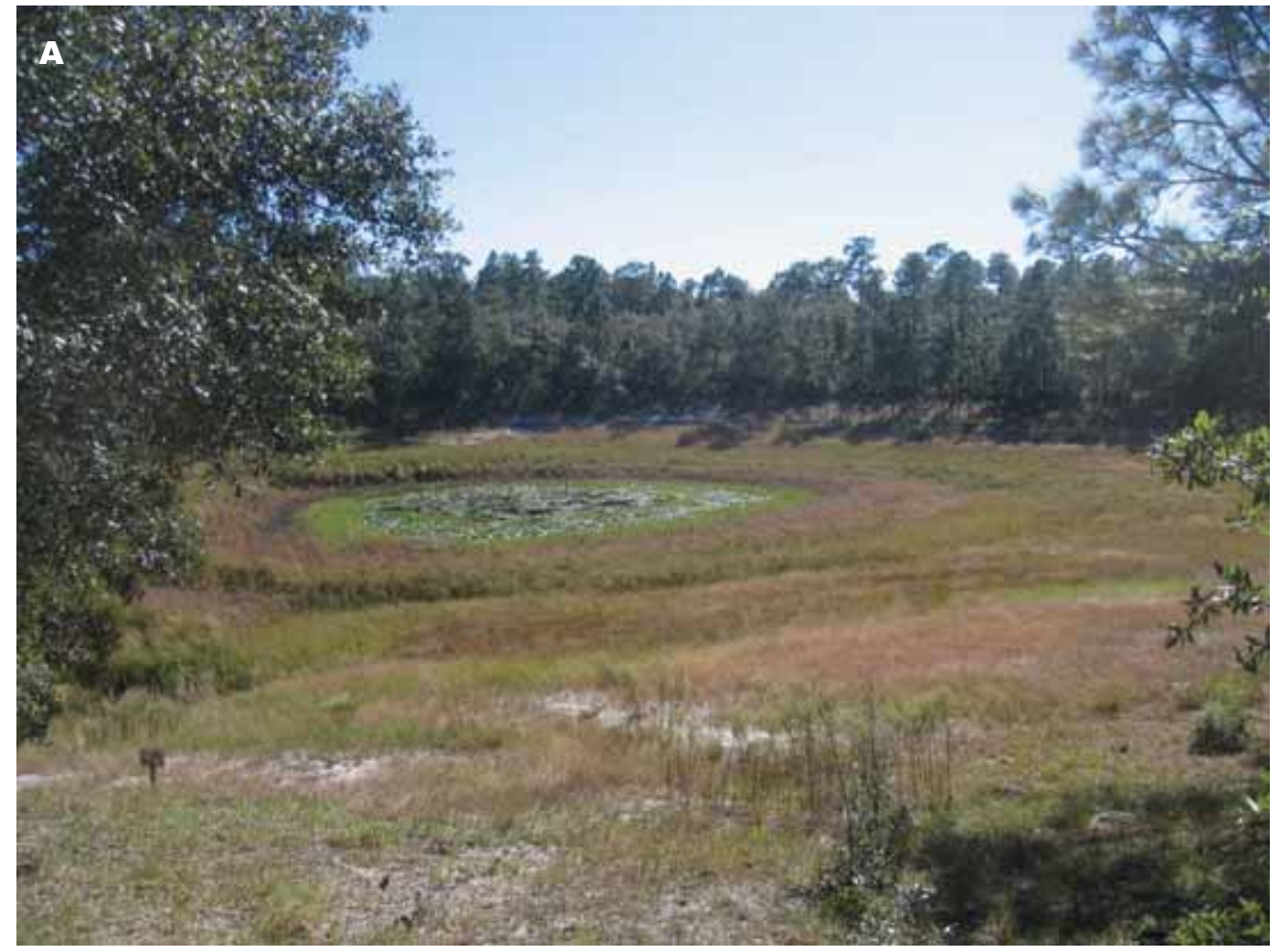



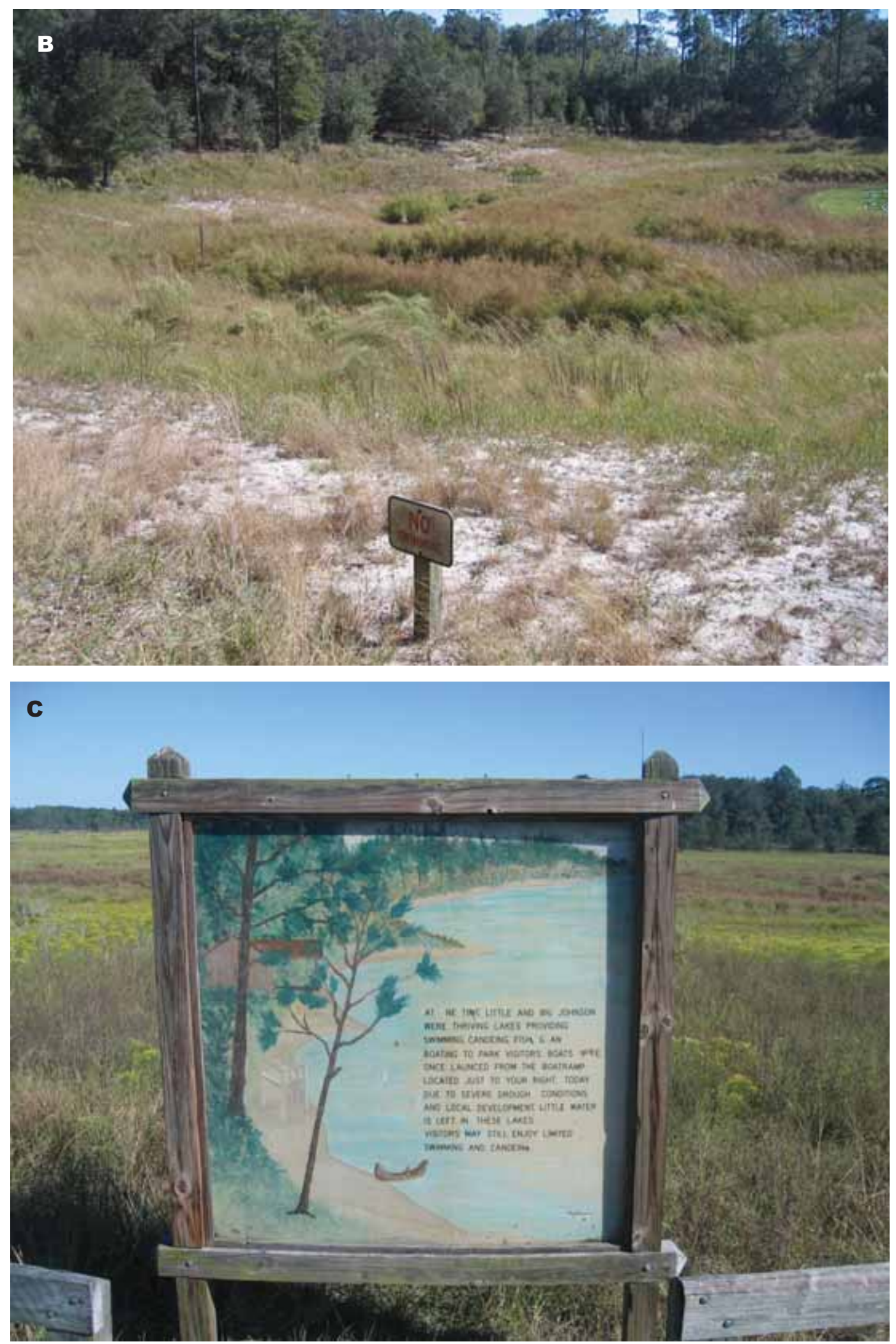

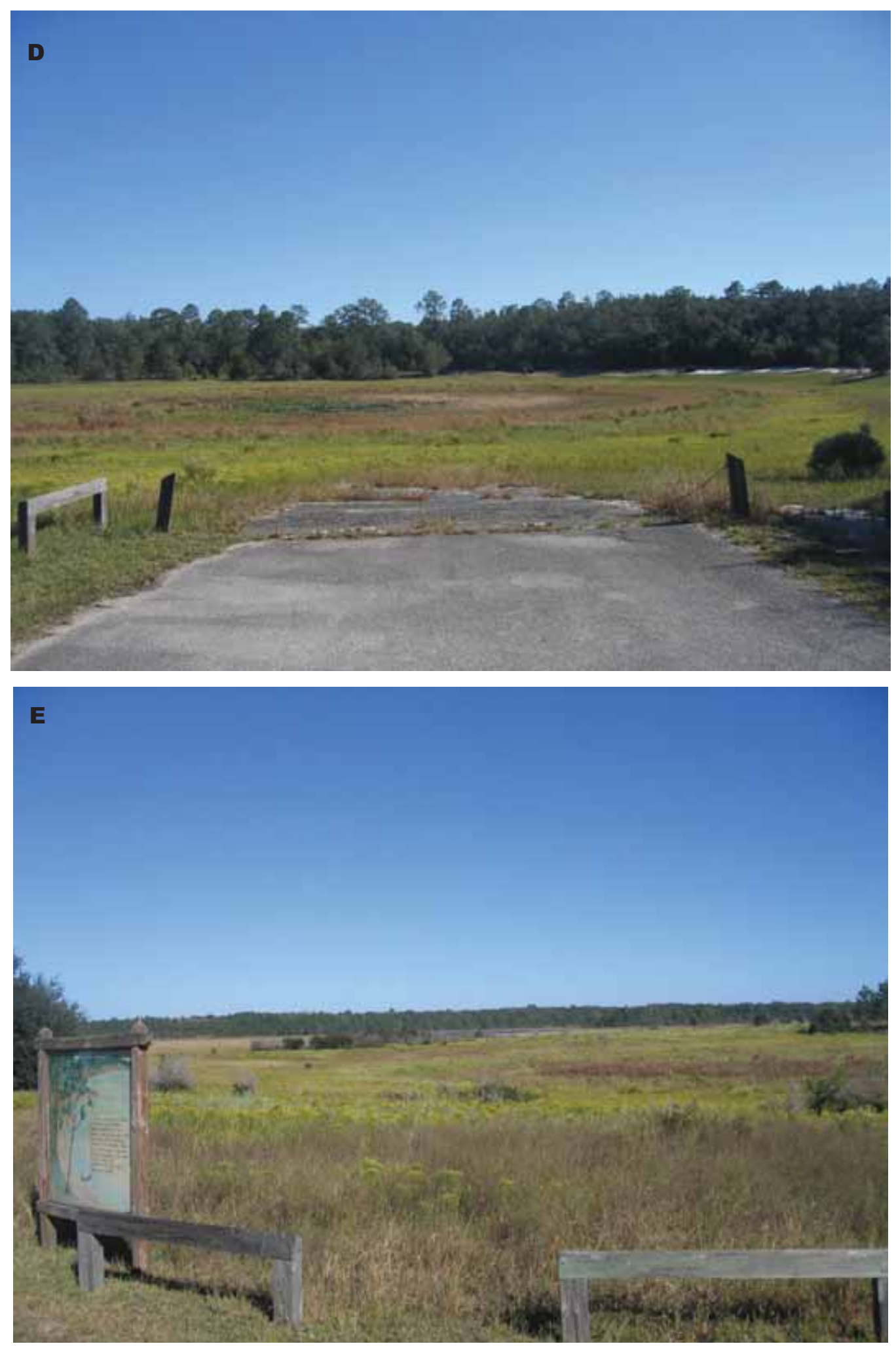

Figure 10. Examples of adverse environmental impacts from hydroperiod alterations in Gold Head Branch State Park in:

A. small natural sinkhole lake with B. enlargement of "No Swimming" sign near dewatered lake;

C. dewatered Johnson Lake with sign depicting historic water level near the tree line;

D. dry lake bed and boat launch referenced in the Johnson Lake sign and

E. dry lake bed in foreground behind Johnson Lake sign, with small area of remaining water in the background 
Figure 11A shows a private dock elevated above part of the dry lake bed of Brooklyn Lake (foreground), west of State Road 21. Figure 11B is an enlargement of that dock, with the tree line in the background representing the approximate historic water level of Brooklyn Lake. Figure 11C shows private docks elevated above a more extensive dewatered area of Brooklyn Lake, east of State Road 21, with the tree line in the background again representing the approximate historic water level of Brooklyn Lake. The dry lake bed is covered with numerous sandy trails of various widths, ranging from game trails and foot paths to those used by motorized vehicles.
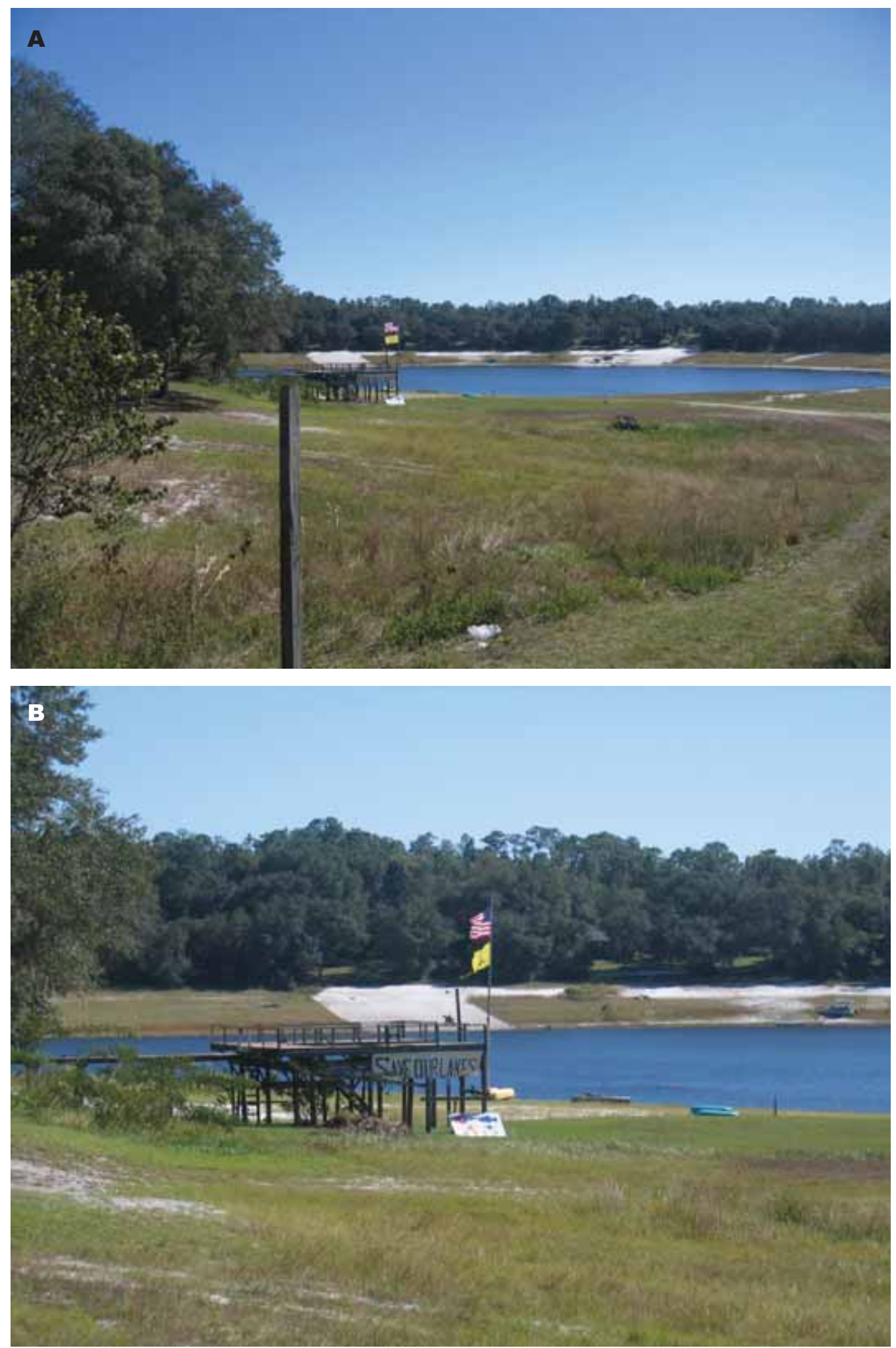


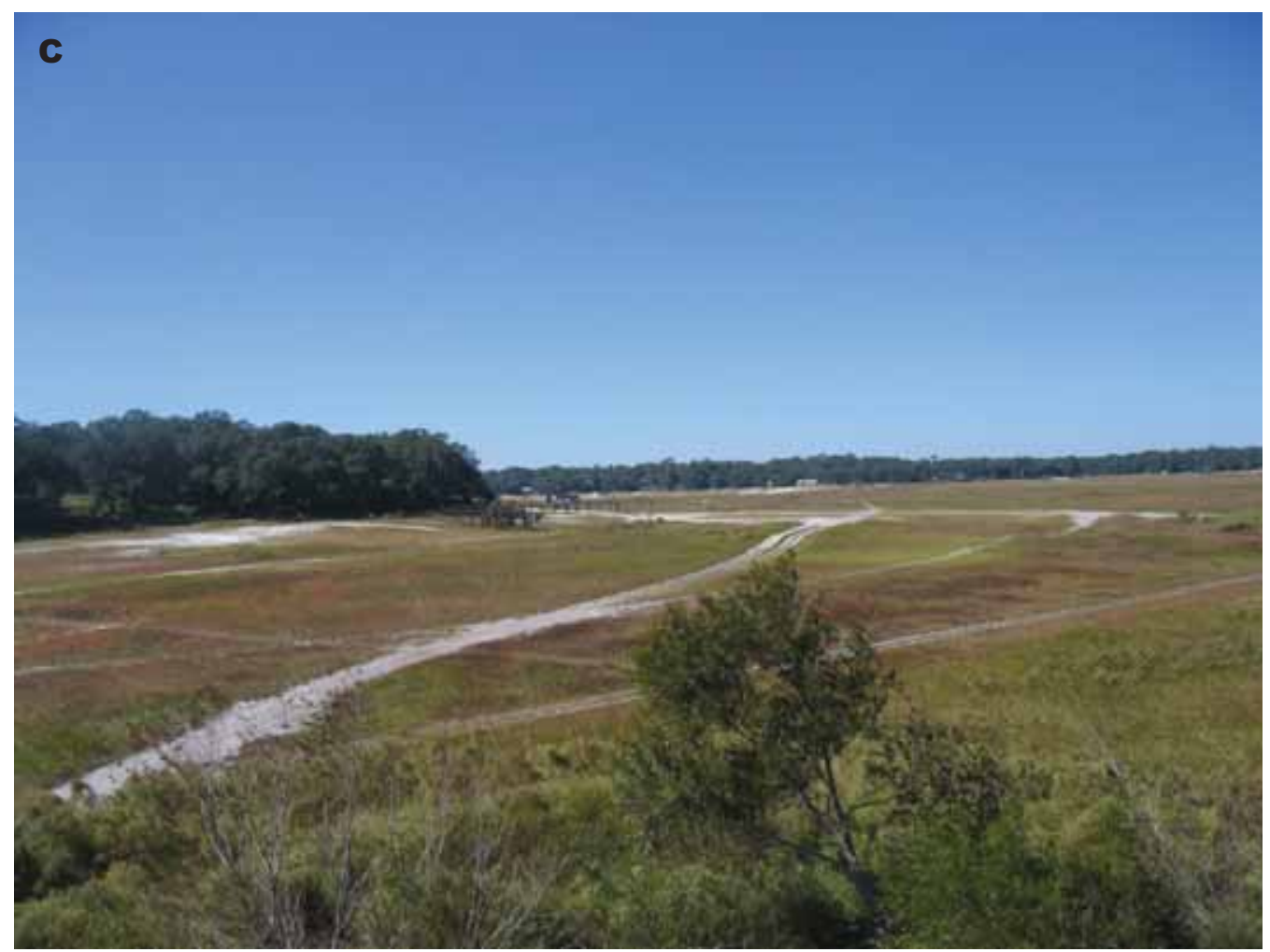

Figure 11. Examples of adverse environmental impacts from hydroperiod alterations in Clay County lakes with privately owned lake-front property:

A. private dock elevated above dry lake bed of Brooklyn Lake west of State Road 21;

B. enlargement of that dock and tree line representing the approximate historic water level; and

C. private docks elevated above dewatered Brooklyn Lake east of State Road 21

Figure 12 shows a dewatered tributary (bottom right) in western Jennings State Forest, in the vicinity of the initial DuPont Trail Ridge Mine. Dead and declining trees, shown in the background of Figure 12, are concentrated near the tributary. Immediately behind co-author Bacchus in Figure 12 is the largest specimen of dogfennel (Eupatorium capillifolium) documented in her 40

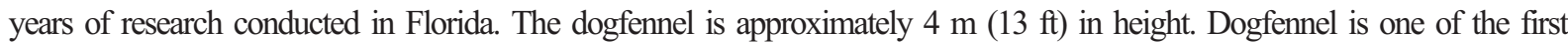
invasive species to appear after natural hydroperiods are altered. The large size of the dogfennel and concentration of dead and declining trees in the vicinity of the tributary provide two forms of evidence that hydroperiod alterations of that area were initiated many years ago and are continuing, particularly based on the length of time required for trees subjected to chronic water stress from hydroperiod alterations to die. 


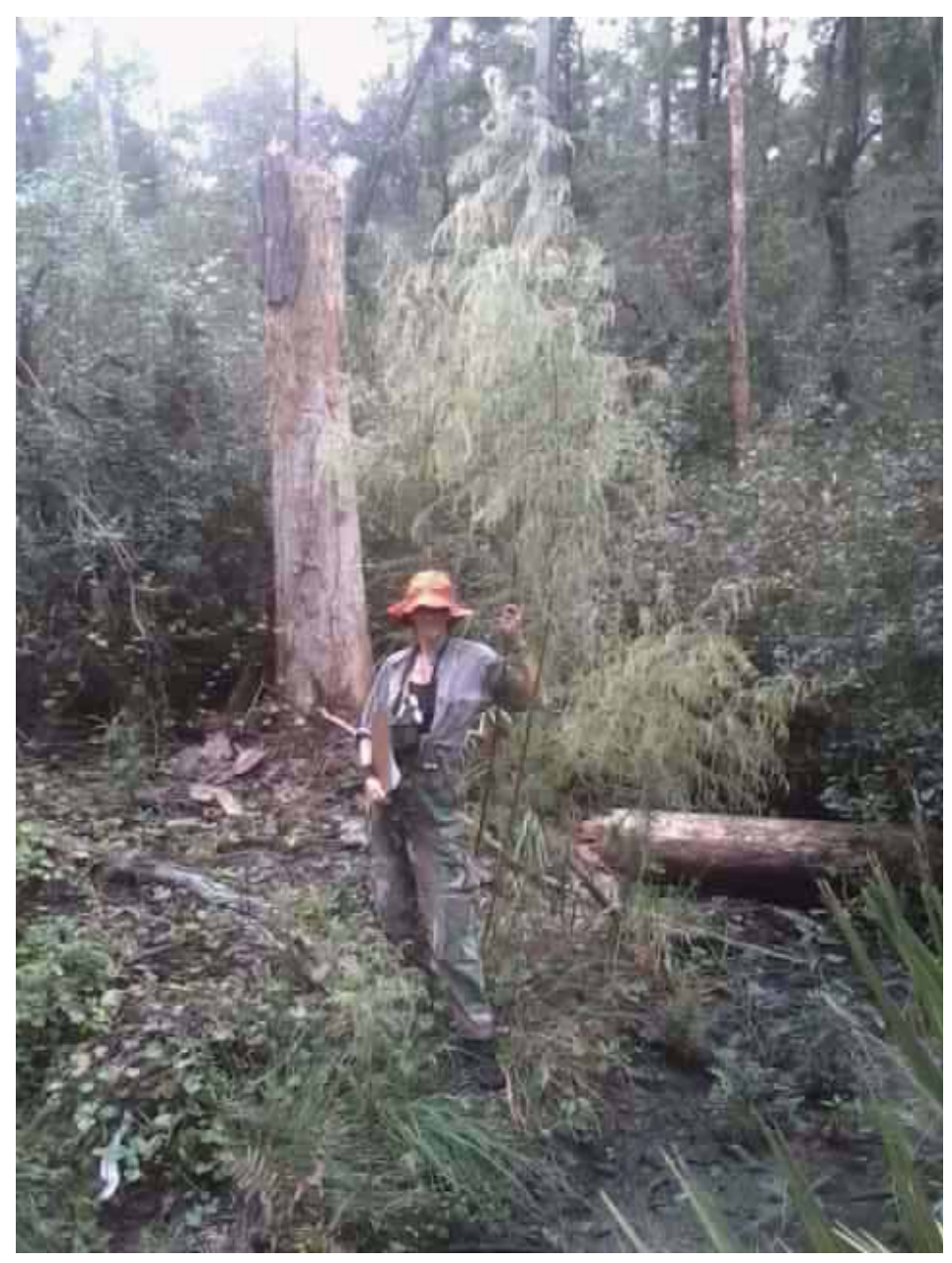

Figure 12. Examples of adverse environmental impacts from hydroperiod alterations at dewatered tributary in Jennings State Forest

\subsection{The Relationship between Fractures and Sinkholes}

Large conductive fractures dominate fluid flow in the subsurface (Ortega, Marrett, \& Laubach, 2006) and are important in controlling the orientation of solution channels and development of circulation patterns in ground water (Faulkner, 1973), thus influencing well productivity (Brook, 1985; Brook, Sun, \& Carver, 1988). Sinkhole development over geologic time can occur along linear features and conduits of any scale (Littlefield, Culbreath, Upchurch, \& Stewart, 1984). The distribution and shape of sinkholes in the FAS have been used to map fractures in the Ocala limestone (Brook \& Allison, 1983). Brook and Sun (1982) illustrated how relict sinkholes, including depressional wetlands and open-water areas ranging in size from ponds to lakes, are aligned along fractures throughout the FAS. The non-random distribution of solution features is controlled by regional joint patterns and extends beyond the present-day shoreline, in the submarine platform of the Floridan aquifer, where the most pronounced deformation from solution follows the reef and back-reef edge of the Late Cretaceous-Paleocene carbonate platform and collapse and filling of submarine sinkholes is a process that continues today (Popenoe, Kohout, \& Manheim, 1984). Therefore, the increased probability of subsidence such as sinkholes is associated with fractures (Brook \& Sun, 1982; Littlefield, Culbreath, Upchurch, \& Stewart, 1984). One of the procedural steps recommended for sinkhole analysis by Ogden (1984) is the use of photo-lineament trends, further emphasizing the functional relationship between fractures and sinkholes. Hall and Metcalfe (1977) used the remote sensing technique of fracture trace lineament analysis to assess the potential for sinkhole occurrences in the vicinity of multiple large-scale mining projects in west-central Florida. Casper, Byron, and Degner (1981) conducted a more extensive analysis of that area using aerial photography and Landsat orbital color-infrared imagery and concluded that many of the new sinkholes appeared to be located in proximity to mapped fracture-traces or lineaments and the intersections between those features. Increased probability of subsidence such as sinkholes is associated with fracture intersections (Brook \& Sun, 1982; Littlefield, Culbreath, Upchurch, \& Stewart, 1984) and new sinkholes are known to form from the loss of hydrostatic support following withdrawals of large quantities of water from the artesian Floridan aquifer 
(Metcalfe \& Hall, 1984). Therefore, frequency and distribution of fracture intersections are important considerations for insuring that proposed developments will be sustainable.

The shortest distances from sinkholes to fractures and fracture intersections shown in Table 4 reveals that the modern sinkholes reported in the state database are more closely associated with the fractures and intersections mapped using satellite images (FDOT, 1973) than with aerial photographs (Vernon, 1951). This is consistent with the results from similar analyses of the proximity of modern sinkholes in Citrus and Levy Counties, where all modern sinkholes from the state database were located within $2.75 \mathrm{~km}$ (1.7 mi) of a fracture mapped by FDOT (1973). When the two data sets for fractures in Citrus and Levy Counties were combined, all modern sinkholes were located within 250 meters of a fracture (Lines et al., 2012). Although the state database reported no modern sinkholes for Baker County and only three for Clay County, our study identified 220 fracture intersections in Baker County and 610 in Clay County (Table 3) for the fractures mapped by Vernon (1951) and FDOT (1973). The number of fracture intersections in Baker County is similar to the number of fracture intersections for Citrus and Levy Counties, 210 and 200, respectively (Lines et al., 2012). The fact that the number of fracture intersections in Clay County is approximately three times the number of fracture intersections in Baker, Citrus and Levy Counties should suggest that mining and other projects that result in groundwater alterations would have a considerably greater potential for adverse environmental impacts. In fact, Figure 9 shows that fractures intersect two of the supply wells permitted for the initial DuPont Trail Ridge Mine and the remaining five supply wells for that mine are in proximity to fractures and fracture intersections. Those conditions would magnify the adverse groundwater impacts solely from the mining.

The tendency for more sinkholes to be reported in highly urbanized areas may be because sinkholes are discovered more readily where populations are denser and the sinkholes affect more people or because urbanized areas actually create more sinkholes (Littlefield, Culbreath, Upchurch, \& Stewart, 1984). As an example, no modern sinkholes were reported in one area of Florida until approximately 1981, after initiation of grading for a highway project and operations of a limestone mine began adjacent to the highway project in 1983, leading to the formation of sinkholes in the highway and swallets in the roadside ditches due to changes in the water table and flow gradient (Koch, 1984). Similarly, since 1900, approximately 4,000 human-induced sinkholes formed in Alabama, compared to an estimated 50 natural collapses. Induced sinkholes result from construction or decline in the water table primarily due to: (a) loss of buoyant support; (b) increase in the velocity of movement of ground water; (c) water table fluctuations at the base of unconsolidated deposits; and (d) induced recharge (Newton, 1977). The FAS extends through the coastal plain of Alabama (Krause \& Randolph, 1989). Consequently, based on those findings, fewer sinkholes may have been reported for Baker and Clay Counties because of the rural nature of those counties and the formation of additional sinkholes may be induced in those counties in our northeast Florida study area by the proposed mining and groundwater supply wells.

Another reason that no modern sinkholes were included in the state sinkhole database for Baker County and only three were included for Clay County may be that the state sinkhole database (http://fcit.usf.edu/florida/maps/) only includes sinkholes reported through 2008. Other sinkholes may have occurred in the study area since 2008. That database also does not include relict sinkholes, only modern sinkholes. Littlefield, Culbreath, Upchurch, and Stewart (1984) reported that linear features can be detected at all scales by the presence of ancient sinks, which are synonymous with relict sinkholes. Their study used USGS quadrangle maps to identify topography and closed depressions to identify 2,303 relict sinkholes in one county, more than an order of magnitude greater than the 138 modern sinkholes identified in that county. Use of remote imagery in that study included 1:20,000 aerial photographs for location of fracture traces and 1:500,000 Landsat images for recognition of lineaments. Geophysical methods included horizontal electrical profiles, vertical electrical soundings, tri-potential profiles, and microgravity and triple-track gravity profiles in that study.

Depressional wetlands, such as pond-cypress (Taxodium ascendens) wetlands, represent one type of ecosystem located in relict sinkholes. These cypress wetlands occur throughout the extent of the FAS, are the primary type of wetland throughout the proposed Levy nuclear plant site and surrounding vicinity and also occur in Baker County. Sinkhole lakes represent another relict-sinkhole ecosystem type characteristic of the FAS. A detailed description of sinkhole lakes in Florida is provided by FNAI and Florida Department of Natural Resources (1990). The dark, circular areas in the southern half of the ESRI World Imagery satellite image used as the base map in Figure 9 are sinkhole lakes. All three of the modern sinkholes reported for Clay County (Figure 9) are associated with sinkhole lakes (relict sinkholes). Also apparent from Figure 9 is the relative absence of fractures mapped by Vernon (1951) and FDOT (1973) in the vicinity of sinkhole A. A plausible explanation may be the extensive surface and vegetation alterations in that area that may have occurred as part of the Camp Blanding Military Reservation operations before the Vernon (1951) and FDOT (1973) maps were produced. Another important consideration is that in many cases, microfracture abundance is related directly to macrofracture abundance (Marrett, Ortega, \& Kelsey, 1999; Ortega \& Marrett, 2000), but microfractures were not mapped by Vernon (1951) or FDOT (1973). No claims were made by Vernon (1951) or FDOT (1973) that the mapped fractures were the only fractures in those counties (Faulkner, 1973).

Reporting only the number and location of sinkholes also ignores the fact that individual sinkholes coalesce with lateral increase in size (Brook \& Allison, 1983). The locations of the three modern sinkholes reported in Clay County, in proximity to the sinkhole lakes (Figure 9), suggests that these modern sinkholes are coalescing with the relict sinkholes. This raises additional 
concerns that the initial DuPont Trail Ridge Mine and its supply wells could be responsible for dewatering some of the sinkhole lakes in the surrounding area. In addition, mining and other projects that result in groundwater alterations, but do not create many new sinkholes, most likely are dewatering sinkhole lakes, depressional wetlands and streams in the vicinity. The relict sinkholes in Baker and Clay Counties were not mapped in our study. A comparison of modern and relict sinkholes in Baker and Clay Counties, however, should confirm that relict sinkholes are more abundant than modern sinkholes reported in the state database in those counties.

The relationship between fractures and sinkholes can be seen more clearly in the vicinity of the phosphate mines in west-central Florida (Figure 13A-C). Figure 13C is an enlargement of Figure 13B in the location of the cluster of active, inactive and proposed phosphate mines. This area also includes a dense network of fractures that extend north, east, south and west for many kilometers beyond the boundaries of those mines, including fractures extending to and through the area of the recent sinkholes shown in Figures 13A and B. The multiple dark and green geometric signatures in the aerial imagery of Figure 13C are mined areas that previously were ground water, but now are exposed (daylighted) as the result of those mining operations. Six new sinkholes (Figure 13A, yellow circles), including a lethal sinkhole, opened in that vicinity while the USACE was evaluating the areawide direct, secondary and cumulative impacts of multiple existing and proposed phosphate mines. The hydrologic model created by CH2M Hill for the USACE to evaluate those impacts did not include modeled flow through those fractures (USACE, 2012; 2013). All of those new sinkholes are located in Seffner (Hillsborough County), Florida, northwest of the area of extensive existing and proposed phosphate mines (Figure 13B and 13C). Table 5 includes the date each of the new sinkholes opened during February through April, 2013 and the coordinates and address of each sinkhole. All but the third sinkhole resulted in property damage, based on unpublished data from the Florida Geological Survey (FGS).

Table 5. New sinkholes in Seffner (Hillsborough County), Florida associated with fractures mapped by Vernon (1951) and FDOT (1973) that extend through existing and proposed phosphate mine areas

\section{Coordinates}

\begin{tabular}{ccrll} 
Sinkhole ID & Date & Longitude $(\mathbf{W})$ & Latitude $(\mathbf{N})$ & \multicolumn{1}{c}{ Address } \\
\hline 1 & $2 / 28 / 13$ & -82.281159 & 27.971181 & 240 Faith Way Drive \\
2 & $3 / 4 / 13$ & -82.294728 & 27.988304 & 1204 Cedar Tree Lane \\
3 & $3 / 9 / 13$ & -82.27896 & 27.99446 & 107 Cash Drive \\
4 & $3 / 23 / 13$ & -82.26261 & 27.97771 & 1427 Lake Shore Ranch Dr \\
5 & $3 / 26 / 13$ & -82.29674 & 27.99352 & 5315 Peach Ave \\
6 & $4 / 11 / 13$ & -82.29566 & 27.99033 & 5218 Lime Avenue \\
\hline
\end{tabular}

The first new sinkhole resulted in the death of Seffner resident, Jeff Bush, when he and the bedroom of his house were swallowed by that sinkhole while he was sleeping. That sinkhole was recorded by the FGS as 50-feet (15.2-m) deep and 50-feet wide. All of the sinkholes except the third sinkhole resulted in property damage. Photographs of the lethal sinkhole and the destruction it caused to homes and surroundings were provided by USA Today (http://www.usatoday.com/story/news/nation/2013/03/04/sinkhole-home-florida/1961997/). The first new sinkhole, which resulted in the death of Mr. Bush, is associated with a fracture mapped by FDOT (1973) that extends into and through the area of the phosphate mines reportedly evaluated in the final areawide EIS (Figure 13A-C). That fracture also extends through an existing sinkhole from the state database (blue circle) that is located in proximity to the lethal sinkhole and at an intersection with another fracture mapped by FDOT (1973). The second new sinkhole that opened in Seffner is located in proximity to another fracture mapped by FDOT (1973) that intersects the fracture associated with the sinkhole responsible for the death of Mr. Bush. New sinkholes 2, 5 and 6 are aligned in a linear pattern in proximity to an existing sinkhole from the state database. The linear alignment of those four sinkholes suggests they are associated with a fracture oriented northwest to southeast that was not mapped by Vernon (1951) or FDOT (1973). New sinkholes 3 and 4 are located northwest of another existing sinkhole from the state database. Those sinkholes are in proximity to the unmapped extension of a fracture to the southeast, mapped by Vernon (1951). The alignment of those sinkholes suggests that fracture extends to the northwest, through those sinkholes (Figure 13A).

Popenoe, Kohout, \& Manheim (1984) documented the extension of previously mapped fractures in areas of Florida beyond the present-day shoreline in the submarine platform of the Floridan aquifer, where dissolution of Eocene and Oligocene rocks follow fractures caused by deep collapse, and sinkholes propagate to the surface through the overlying Neogene section along these trends. Raabe \& Bialkowska-Jelinska (2010) used hypothetical extensions of previously mapped fractures in their west-central Florida study area to discuss the potential environmental implications of those geological features. If the fracture aligned with the third new sinkhole and existing sinkhole from the state data base also is extended to the southwest, it would extend through the 
cluster of phosphate mines included within the larger white square in Figure 13B. The larger white square shows the area of some of the active and inactive phosphate mines reportedly evaluated in the areawide EIS (USACE, 2013). The boundaries of Hillsborough, Polk, Manatee, Hardee, Highlands and Osceola Counties are shown in black in Figure 13B. The smaller white square in Figure 13B is the Seffner area where the six new sinkholes appeared. Although not shown in Figure 11B, some of the fractures that dissect the phosphate mining area extend to the coastline of the coastal counties. Therefore, diversion of ground water previously flowing to estuaries and other sensitive coastal areas could have occurred already as a result of groundwater alterations and specifically groundwater depletions caused by active and inactive phosphate mines. The final areawide EIS discussed the role of sinkholes and karst conduits in the aquifer, but did not provide an evaluation of adverse impacts of any of those sinkholes identified above, including the resulting death and extensive property destruction (USACE, 2013). The high connectivity represented by the dense fracture network we observed in the aquifer suggests that effects of water drawdown may be greater than the localized effects predicted by the EIS.

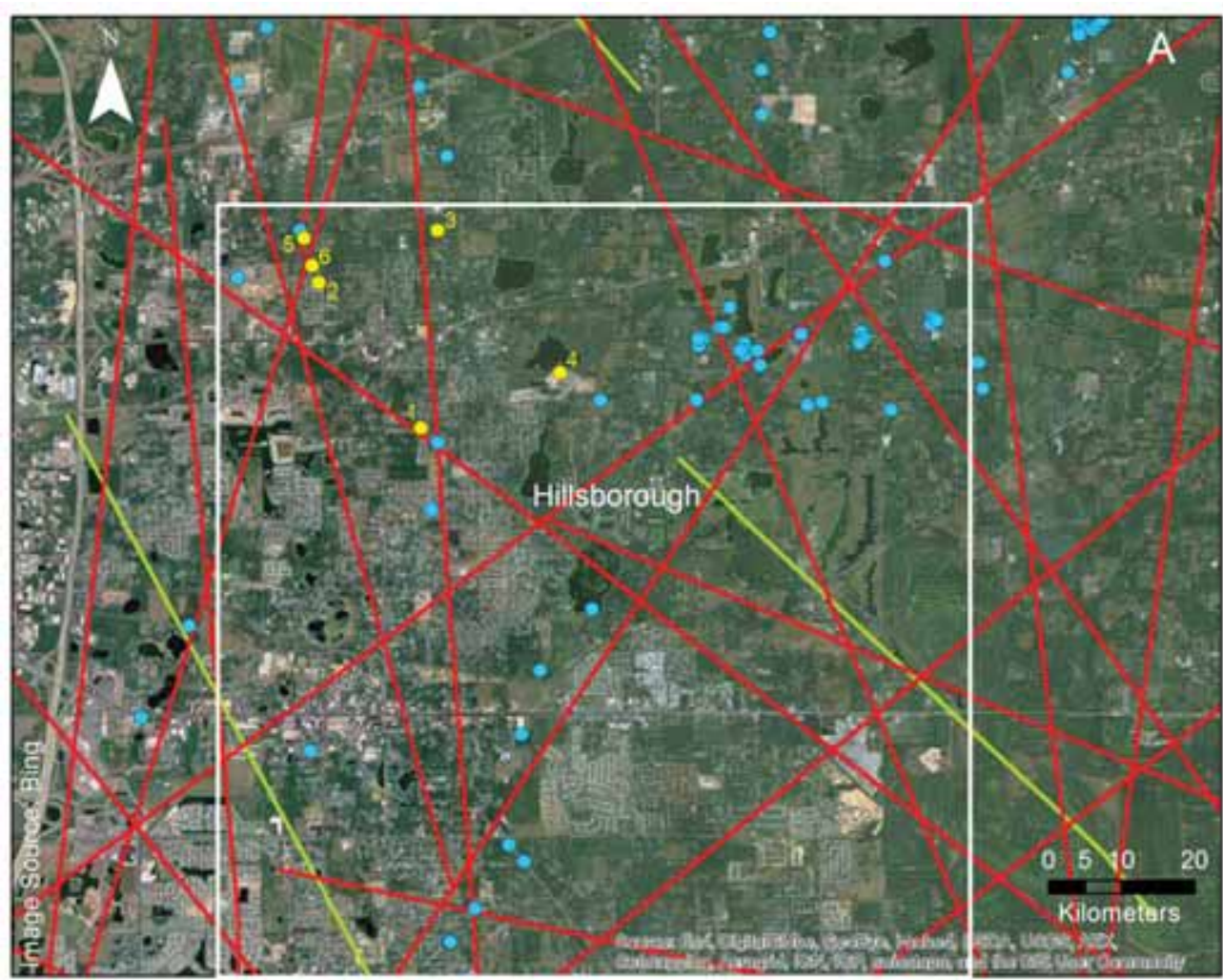



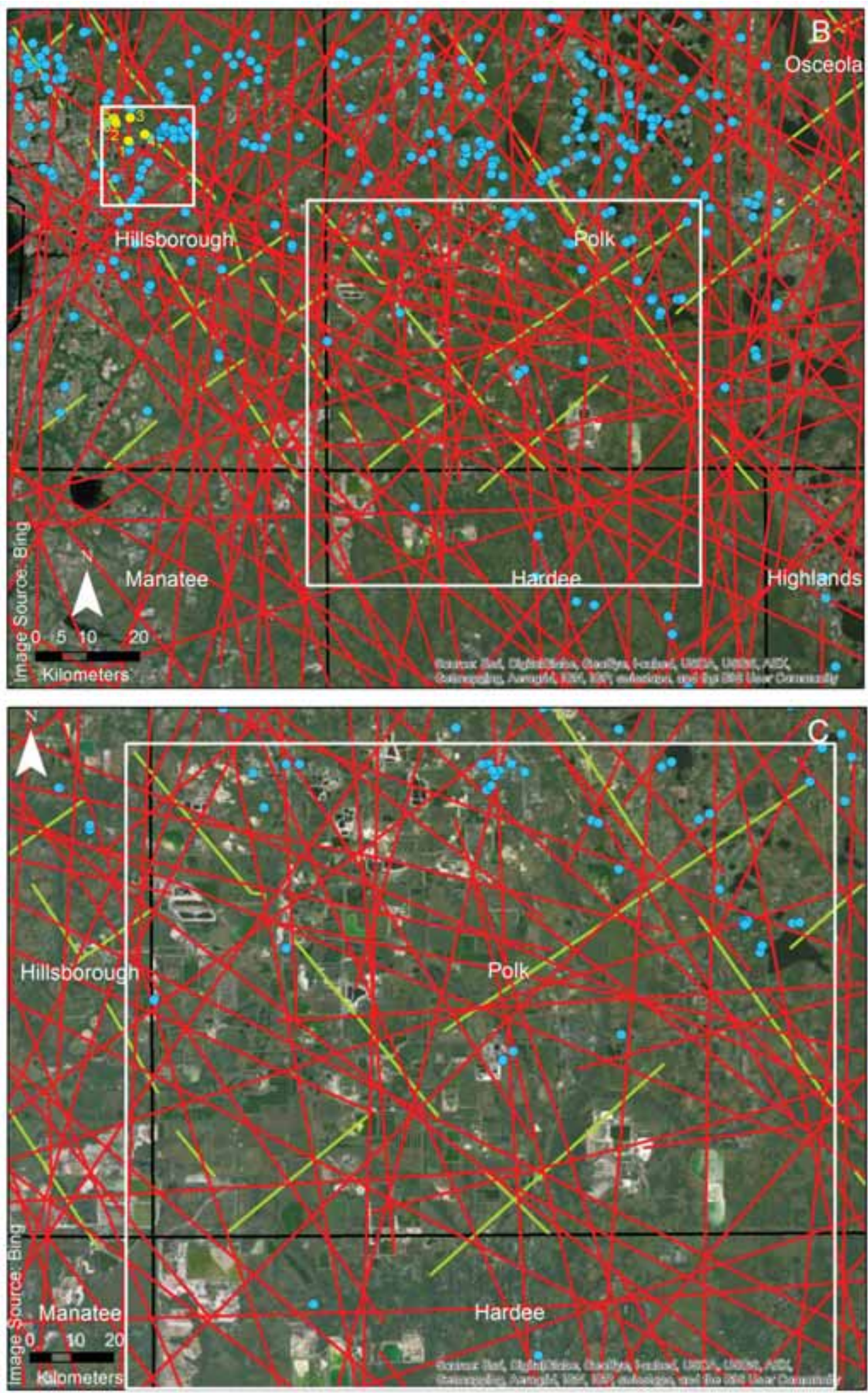

Figure 13. Modern sinkholes from state database (blue circles) associated with fractures mapped by Vernon (1951, yellow diagonal lines) and FDOT (1973, red diagonal lines) and

A. six new sinkholes opening in 2013 (yellow circles) in vicinity of west-central Florida phosphate mining area;

B. proximity of six new sinkholes to fractures extending through mining areas in Polk and Hardee Counties;

C. enlargement of mining areas in Polk and Hardee Counties, with fractures and modern sinkholes 


\subsection{Drought vs. Anthropogenic Groundwater Impacts}

Environmental damage at Gold Head Branch State Park and Brooklyn Lake, exemplified in Figures 10A through 10D and Figures 11A through 11C, respectively, is attributed to drought by FDEP (Craig Littauer, pers. com., February 2, 2014) and SJRWMD (Canepa, 2014). When requested, neither agency could provide data to support that conclusion (Craig Littauer, pers. com., February 2, 2014; Sandy Bertram, pers. com., March 24, 2014). We investigated variability in precipitation for Baker and Clay counties, including the potential occurrence of periods of severely reduced rainfall that could affect the availability of ground water. Our analysis used non-provisional precipitation surfaces generated by the PRISM Climate Group at Oregon State University (www.prism.oregonstate.edu, accessed on April 12, 2014). Precipitation from PRISM derives from modeling and interpolation of quality-controlled rainfall data from multiple weather stations and incorporates a physiographically sensitive approach for surface generation (Daly et al., 2008). We calculated standardized anomalies of precipitation by subtracting the average annual precipitation for the period 1895-2012 from the total precipitation for a given year. The result was then divided by the standard deviation for annual precipitation for the period 1895-2012 (Figure 14). Precipitation anomalies show considerable variability in total rainfall for the region over the 118 years analyzed, which included multiple instances of relatively wet and dry years. Since the 1960s, wet anomalies have topped dry anomalies when total departures from normal conditions are considered, particularly due to a very wet 1964. Comparisons of total anomalies for each decade following the 1960s showed a decrease in standard units for the difference between wet and dry years (slope $=-1.19$ ). Anomalies for wet and dry years reached similar values in the 1990s and a shift toward relatively drier years in the region can be observed for the $21^{\text {st }}$ century, although wet years were observed in 2004-2005, and as recently as 2012. Premature decline of mature trees now dead in areas of Jennings State Forest and Gold Head Branch State Park, in addition to the dewatering of natural lakes in Gold Head Branch State Park, Lake Brooklyn and surrounding lakes in Clay and Putnam Counties occurred since the 1960s.

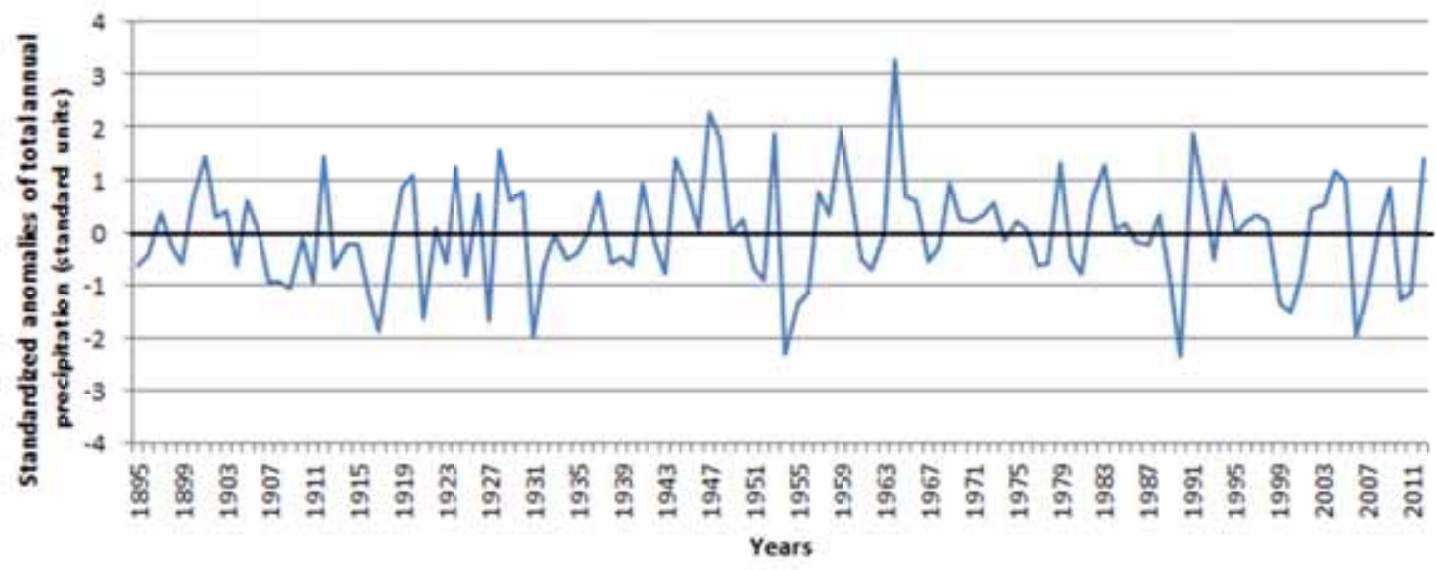

Figure 14. Standardized anomalies from total annual precipitation for 1895-2012

Consumptive use permits (CUP) for mining, other industrial water use and municipal water use in Baker and Clay Counties and surrounding counties are issued by SJRWMD. Although SJRWMD uses water models to evaluate water availability for CUP applications for mining, other industrial and municipal water use, those models do not integrate rainfall data into models evaluating applications to assess water availability (Sandy Bertram, pers. com., March 19 and 21, 2014). The CUPs issued by SJRWMD for mining, like the permit issued for the DuPont mining throughout the study, are issued for a period of 14 years, with repeated permit renewals after each permit expires. The last number in the most recent CUP issued for the DuPont mining, CUP 2-007-433-5, indicates there have been five renewals of that mining permit and the expiration date is "09/07/2024." The SJRWMD did not provide a copy of the original permit or the initiation date for the initial DuPont mine, in the vicinity of Brooklyn Lake, Gold Head Branch State Park and Jennings State Forest. The approximate initiation date for that mining would be 1954, based on five renewal periods of 14 years each and current permit expiration in 2024. The current permit for DuPont's mining authorizes groundwater withdrawals from the lower, intermediate and upper zones of the FAS, in addition to 16.56 million gallons per day (MGD) of "surface water from the final effluent pond and zircon pond," based on the "11,500 gallons per minute" figure provided in the permit. In comparison, the CUP that SJRWMD issued to the Clay County Utility Authority on November 8, 2011 for the Keystone Heights System (431) municipal water in the same vicinity as the original DuPont Mine, was for $0.667 \mathrm{MGD}$.

Models that do not consider the influence of fractures and sinkholes or rainfall cannot adequately evaluate adverse environment impacts. Additionally, the reference in the DuPont permit to "11,500 gallons per minute" of "surface water" is misleading 
because the "ponds" are excavated into the surficial aquifer and ground water flows into those excavated "ponds" from surrounding areas to replace the water that is withdrawn by pumping and to replace water that is lost to evaporation. The surficial aquifer not only is the source of recharge for the FAS, natural lakes and streams, it is the primary source of water for the native vegetation, particularly forested areas. This loss of water from ponds and other mine pits excavated into the surficial aquifer is most critical to the environment when ambient temperatures are highest (e.g., summer), during seasonal periods of low rainfall and during periods of drought and represents non-mechanical dewatering of the aquifer system (Bacchus, 2006). These types of mining permits suggest that anthropogenic groundwater alterations, both alone and combined with periods of drought, are responsible for the pattern of adverse environmental impacts occurring in the study area.

Following are definitions of drought:

Drought - a relative term denoting a period during which rainfall is either totally absent or substantially lower than usual for the area in question, so that there is a resulting shortage of water for human use, agriculture, or natural vegetation and fauna. (Allaby, 2008)

"Meteorological Drought

Meteorological drought is defined usually on the basis of the degree of dryness (in comparison to some normal or average amount) and the duration of the dry period. Definitions of meteorological drought must be considered as region specific since the atmospheric conditions that result in deficiencies of precipitation are highly variable from region to region. For example, some definitions of meteorological drought identify periods of drought on the basis of the number of days with precipitation less than some specified threshold. This measure is only appropriate for regions characterized by a year-round precipitation regime such as a tropical rainforest, humid subtropical climate, or humid mid-latitude climate. Locations such as Manaus, Brazil; New Orleans, Louisiana (U.S.A.); and London, England, are examples. Other climatic regimes are characterized by a seasonal rainfall pattern, such as the central United States .... Other definitions may relate actual precipitation departures to average amounts on monthly, seasonal, or annual time scales." (National Drought Mitigation Center, 2014)

"Hydrological Drought

Hydrological drought is associated with the effects of periods of precipitation (including snowfall) shortfalls on surface or subsurface water supply (i.e., streamflow, reservoir and lake levels, groundwater). The frequency and severity of hydrological drought is often defined on a watershed or river basin scale. Although all droughts originate with a deficiency of precipitation, hydrologists are more concerned with how this deficiency plays out through the hydrologic system. Hydrological droughts are usually out of phase with or lag the occurrence of meteorological and agricultural droughts. It takes longer for precipitation deficiencies to show up in components of the hydrological system such as soil moisture, streamflow, and groundwater and reservoir levels. As a result, these impacts are out of phase with impacts in other economic sectors. For example, a precipitation deficiency may result in a rapid depletion of soil moisture that is almost immediately discernible to agriculturalists, but the impact of this deficiency on reservoir levels may not affect hydroelectric power production or recreational uses for many months. Also, water in hydrologic storage systems (e.g., reservoirs, rivers) is often used for multiple and competing purposes (e.g., flood control, irrigation, recreation, navigation, hydropower, wildlife habitat), further complicating the sequence and quantification of impacts. Competition for water in these storage systems escalates during drought and conflicts between water users increase significantly.” (National Drought Mitigation Center, 2014)

\subsection{Adverse Impacts to Mitigation Banks and Other Conservation Areas from Hydroperiod Alterations}

The U.S. Clean Water Act (CWA) of 1972 (33 U.S.C. $\$ 1251$ et seq.), summarized at $\mathrm{http}: / / \mathrm{www} 2$.epa.gov/laws-regulations/summary-clean-water-act, requires that all direct, indirect and cumulative impacts of developments that would result in the discharge of material into wetlands, such as existing and proposed mining in Baker and Clay Counties be assessed. Cumulative impacts (effects) were defined by 40 CFR $\S 1508.7$ as "the impact on the environment which results from the incremental impact of the action when added to other past, present, and reasonably foreseeable future actions regardless of what agency (Federal or non-Federal) or person undertakes such other actions." Cumulative impacts of groundwater pumping have resulted in significant impacts to existing legal users (shallow wells) and property damage from sinkholes are well documented and resulted in several studies conducted in the vicinity of phosphate mining in west-central Florida, documenting approximately 760 dry wells and 140 sinkholes created within 10 miles $(16 \mathrm{~km})$ of the drawdown in that area (Peterson \& Rumbaugh, III, 2012). Bacchus (2001), Bacchus et al. (2003) and Bacchus, Archibald, Britton, and Haines (2005) provided examples of the types of cumulative adverse environmental effects from hydroperiod alterations, like those that would occur from the proposed mines in our northeast Florida study area. Lines et al. (2012) included the definition of hydroperiod, more detailed discussions and photographs of environmental damage from cumulative impacts of hydroperiod 
alterations that also are relevant to the northeast Florida study area, with emphasis on adverse impacts to wildlife habitat such as wetlands throughout the FAS, including habitat critical for the survival and recovery of threatened and endangered species. Those impacts also were addressed by Bacchus $(1998 ; 2006)$ and include destructive fires and premature decline and death of trees from hydroperiod alterations. Impacts such as bark beetle infestations and fungal infections have been shown to occur in the absence of, or to precede destructive wildfires that further injure or destroy stem, crown, or root tissues in areas where the natural defenses of trees have been compromised by hydroperiod alterations (Bacchus, 2007; Bacchus et al., 2003; Bacchus, Archibald, Britton, \& Haines, 2005). Authors who have considered bark beetle infestations (Dixon, Corneil, Wilkinson, \& Foltz, 1984; McHugh, Kolb, \& Wilson, 2003; Menges \& Deyrup, 2001) and fungal infections (Otrosina, Bannwart, \& Roncadori, 1999; Otrosina, Hess, Zamoch, Perry, \& Jones, 1997) as responses to fire, or second-order fire effects resulting in post-fire tree decline and mortality have not evaluated hydroperiod alterations as the triggering mechanism for destructive fire in their research. These adverse impacts also include disruption of the natural hydroperiod during the period from mating to emergence of frogs, which can eliminate an entire year of reproduction for that link in the food chain (Moler \& Franz, 1987). This emphasizes the fact that the lifecycles of wetland plants and animals are adapted to fluctuating water levels and if the duration, extent, or seasonality of those natural fluctuations is altered, those fluctuations can be fatal for an entire generation or all future generations.

Surficial-aquifer excavations, such as those that occurred with the DuPont Trail Ridge Mines and Florida Rock Vulcan Mine would occur with the proposed Old Castle mine, result in the following categories of alterations of the natural hydroperiod: (a) nonmechanical (passive) groundwater withdrawals, (b) physical displacement of water in the surficial aquifer and (c) capture and impoundment of overland flow (Bacchus, 2006). Nonmechanical dewatering occurs from mines, stormwater ponds and other excavations into the surficial aquifer due to evaporative loss following conversion of groundwater areas to surface waters, and results in the greatest environmental harm, including chronic water stress, during normal dry seasons and periods of abnormally low rainfall. Swancar, Lee, and O'Hare (2000) provided a description of how groundwater flow in the FAS from the surrounding basin plays an important role in maintaining surfacewater levels when net precipitation is negative (less than evaporative loss) over the long term. Physical displacement of ground water occurs because ground water in surrounding areas flows into the large void space created in the surficial aquifer after excavated material is removed. Subsequently there will be a new, lower equilibrium for the water table that will result in less ground water available to surrounding areas. Capture and impoundment of water that previously would have flowed to down-gradient wetlands, streams or coastal areas results from berms and raised dikes generally required in mining projects (Bacchus, 2006). Adverse environmental impacts from hydroperiod alterations, such as oxidation of organic soils and destructive wildfires, cannot be reversed after mining has occurred or even pumping that is reduced or halted (Bacchus, 2006; Southwest Florida Water Management District, 1996; Stewart \& Stedje, 1990; Watson, Stedje, Barcelo, \& Stewart, 1990). Based on the preceding descriptions of how hydrologic alterations permeate beyond the point of origin through fractures and sinkholes, both modern and relict, adverse environmental impacts to off-site mitigation banks, parks, state and national forests and other conservation areas should be expected to occur throughout the FAS.

\subsection{Evaluation Alternatives}

The U. S. Council on Environmental Quality, Executive Office (1997) of the President published a report in January 1997 entitled, "Considering Cumulative Effects Under The National Environmental Policy Act" (Cumulative Effects Report), to address the "incremental loss of wetlands under the national permit to dredge and fill and from land subsidence" that may last for many years beyond the life of the action that caused the effects (e.g., acid mine drainage, radioactive waste contamination, species extinctions). Lines et al. (2012) included a list and discussion of the eight types of cumulative effects from Table 1-3 of the National Environmental Policy Act (NEPA) Cumulative Effects Report to ensure sustainable development. The evaluation procedures described in the Cumulative Effects Report can be applied to all proposed projects to reduce adverse impacts to mitigation and conservation areas, even if permits from federal agencies are not required. Subsidence susceptibility models of future sinkhole development in the FAS suggested that the most important measures of susceptibility to future sinkhole development were the number of sinkholes and number of fractures in a cell, followed by the number of fracture intersections and length of fractures in a cell, suggesting that sinkhole and bedrock fracture data can be used to develop relatively accurate ground subsidence susceptibility maps in the FAS and similar karst areas (Brook \& Allison, 1983). Procedures described by Ogden (1984) should be considered. Geophysical profiling methods using appropriate electrode spacing are effective in locating the center of a fracture zone (Stewart \& Wood, 1984). Because fractures and associated dissolution features can be major subsurface channels for groundwater flow, physical and chemical tracers can be used to characterize subsurface conditions. Physical tracers include water temperature differences, such as those used in the thermal infrared evaluation in the study area by Raabe and Bialkowska-Jelinska (2010). More common tracing agents are contaminants, such as those described by Bacchus and Barile (2005) and those added to water at specific locations in an attempt to identify discharge points and velocity. Non-toxic water-soluble fluorescent dyes are an example of such a tracer.

Kincaid, Davies, Werner, and DeHan (2012) used fluorescent dyes to determine peak tracer travel times and associated minimum groundwater velocities at eight stations associated with the City of Tallahassee's municipal sewage effluent spray field (Southeast Farm Wastewater Reuse Facility) in Leon County, Florida. For those eight stations, the velocities were "maximum 
recorded flow rate: $998 \mathrm{ft} /$ day; average recorded flow rate: $688 \mathrm{ft} /$ day." Five of the eight stations were located approximately 11 miles $(17.7 \mathrm{~km})$, straight-line distances, from the dye-injection locations. Those estimates were considered as minimum velocities because they assume a straight-line flow path. This tracer study led to the conclusion that nitrate-contaminated ground water from Tallahassee's municipal sewage effluent spray field flows predominantly southwestward to Wakulla Spring, in the Wakulla County state park, "at a rate of between 671 and 977 feet per day," with overflow from the primary aquifer conduit also flowing into Indian, Sally Ward and McBride Slough springs. This supports the findings of Bacchus and Barile (2005) that treated sewage effluent is the primary source of nitrogen pollution fueling the growth of alien, invasive and nuisance vegetation in Wakulla Springs. In that dye tracer study, 12 of the 406 samples (three percent) collected from the St. Marks River Rise also contained fluorescent compounds that could be attributed to the injected tracers, compared to approximately 64 percent of samples collected from each of the Wakulla area discharges (Kincaid, Davies, Werner, \& DeHan, 2012). The appearance of fluorescent compounds associated with the St. Marks River, southeast of the sprayfield, was not similar to the flow responses to southwest sites, suggesting the need for additional research to confirm flow to the southeast from the sprayfield (Todd Kincaid, pers. com., December 31, 2013). That dye-tracer study did not consider flow through fractures, which could account for southwest flow at different velocities from southwest flow via sinuous dissolution conduits linked to Wakulla, Indian, Sally Ward and McBride Slough springs.

Compared to alternatives generally implemented, if any site analysis is included during the permitting process, some consider one well-designed tracer test, properly done and correctly interpreted, as worth 100 computer simulations (Quinlan, 1991). For example, Renken et al. (2005) used tracers to calibrate models used in south Florida by regulatory agencies to evaluate the impacts of groundwater flow and potential contamination of municipal supply wells from additional mining proposed in the vicinity of those supply wells. Tracers used in that calibration even revealed groundwater flow occurring in the vicinity of these mine pits that was orders of magnitude greater than predicted by the models developed by the regulatory agencies. Subsequently the conceptualization of groundwater flow in that area was revised, based on the groundwater tracer data (Renken et al., 2008).

We recommend the use of these approaches by permitting and regulatory agencies to evaluate and predict the magnitude and extent of impacts on ground water and surface waters in the FAS for proposed projects involving federal review or the existing and proposed Baker and Clay County projects addressed in our study area. If any evaluation of hydroperiod alteration is attempted, that evaluation typically includes the use of borehole (well) data and MODFLOW models that assume porous-media flow to characterize groundwater flow in Florida's karstic carbonate FAS. The inadequacies of this approach, including the extremely low probability (typically $0.01-0.02$ ) that those boreholes will intersect major subsurface channels, are addressed by Quinlan (1991), Worthington (2003; 2009) and Worthington, Smart, and Ruland (2002).

\section{Conclusions}

As with the related study in Citrus and Levy Counties (Lines et al., 2012), this study also reinforces the importance of evaluating historic geospatial information on lineaments indicative of fractures and associated sinkholes that may predispose affected areas to instability and high transmissivities when planning developments. This type of evaluation is important particularly for projects such as the existing and proposed mines described in this study that are known to alter natural hydroperiods and water quality that are essential for the survival and recovery of wildlife and wildlife habitat, including habitat in mitigation banks and other conservation areas. The network of fractures throughout the northeast Florida study area link existing and proposed mine projects to mitigation banks, parks, state forests and other conservation areas, suggesting that the zone of impact due to cumulative adverse environmental impacts from these proposed projects will have significant adverse environmental impacts on those mitigation banks, parks, state forests and other conservation areas. Thus, more detailed analysis of the off-site impacts of these types of proposed developments should be conducted using geophysical methods such as horizontal electrical profiles, vertical electrical soundings, tri-potential profiles, and microgravity and triple-track gravity profiles, in addition to tracer studies to determine groundwater flow pathways and velocities.

\section{Acknowledgements}

Funding for this case study was provided by the Florida League of Conservation Voters and the University of Georgia Center for Geospatial Research. The authors thank Allison Broughton and Mark Lyons for logistical assistance during site inspections in the study area and for assistance in obtaining agency documents regarding proposed mining projects and water use in the study area. The authors also thank anonymous reviewers for comments that improved the quality of the manuscript and Norman Hopkins for facilitating access to FDOT archive data.

\section{References}

Allaby, M. (2008). A dictionary of earth sciences (3rd ed.). Oxford University Press, Oxford, NY, pp. 197.

Bacchus, S. T. (1998). Determining Sustainable Yield in the Southeastern Coastal Plain: A Need for New Approaches. In J. Borchers, \& C. D. Elifrits (Eds.), Current Research and Case Studies of Land Subsidence (pp. 503-519). Proceedings of the Joseph F. Poland Symposium. 
Bacchus, S. T. (2000). Uncalculated impacts of unsustainable aquifer yield including evidence of subsurface interbasin flow. Journal of American Water Resources Association, 36(3), 457-481. http://dx.doi.org/10.1111/j.1752-1688.2000.tb04279.x

Bacchus, S. T. (2001). Knowledge of groundwater responses - A critical factor in saving Florida's threatened and endangered species. Part I: Marine ecological disturbances. Endangered Species Update, 18(3), 79-90.

Bacchus, S. T. (2006). Nonmechanical dewatering of the regional Floridan aquifer system. In R. S. Harmon, \& C. Wicks (Eds.), Perspectives on karst geomorphology, hydrology, and geochemistry - A tribute volume to Derek C. Ford and William B. White (pp. 219-234). Geological Society of America Special Paper 404.

Bacchus, S. T. (2007). More inconvenient truths: Wildfires and wetlands, SWANCC and Rapanos. National Wetlands Newsletter, 29(11), 15-21.

Bacchus, S. T., \& Barile, P. J. (2005). Discriminating sources and flowpaths of anthropogenic nitrogen discharges to Florida springs, streams and lakes. Environmental \& Engineering Geoscience, 11(4), 293-316.

Bacchus, S. T., Archibald, D. D., Britton, K. O., \& Haines, B. L. (2005). Near infrared model development for pond-cypress subjected to chronic water stress and Botryosphaeria rhodina. Acta Phytopathologica et Entomologica Hungarica, 40(2-3), 251-265.

Bacchus, S. T., Archibald, D. D., Brook, G. A., Britton, K. O., Haines, B. L., Rathbun, S. L., \& Madden, M. (2003). Near infrared spectroscopy of a hydroecological indicator: New tool for determining sustainable yield for Floridan aquifer system. Hydrological Processes, 17, 1785-1809. http://dx.doi.org/10.1002/hyp.1213

Bacchus, S. T., Masour, J., Madden, M., Jordan, T., \& Meng, Q. (2011). Geospatial analysis of depressional wetlands near Peace River watershed phosphate mines, Florida, USA. Environmental and Engineering Geoscience, 17(4), 391-415. http://dx.doi.org/10.2113/gseegeosci.17.4.391

Belt, K., \& Paxton, S. T. (2005). GIS as an aid to visualizing and mapping geology and rock properties in regions of subtle topography. GSA Bulletin, 117(1/2), 149-160.

Brook, G. A. (1985). Geological factors influencing well productivity in the Dougherty Plain covered karst region of Georgia. In Proceedings of the Ankara - Antalya Symposium (pp. 87-99). IAHS Publication no. 161.

Brook, G. A., \& Allison, T. L. (1983). Fracture mapping and ground subsidence susceptibility modeling in covered karst terrain - the example of Dougherty County, Georgia. In Dougherty, P. H. (Ed.), Environmental Karst (pp. 91-108). GeoSpeleo Publications, Cincinnati, OH.

Brook, G. A., \& Sun, C. H. (1982). Predicting the Specific Capacities of Wells Penetrating the Ocala Aquifer Beneath the Dougherty Plain, Southwest Georgia. Technical Completion Report USDI/OWRT Project A-086-GA, Dept. of Geography, UGA, Athens, GA, pp. 86.

Brook, G. A., Sun, C. H., \& Carver, R. E. (1988). Predicting water well productivity in the Dougherty Plain, Georgia. Georgia Journal of Science, 46, 190-203.

Canepa, A. (2014). Sandhill lakes and MFLS. Agenda Item 4. [PowerPoint slides]. Retrieved from http://sjrwmd.iqm2.com/Citizens/FileOpen.aspx?Type=30\&ID=2078

Casper, J., Byron, R., \& Degner J. (1981). A Remote Sensing Evaluation of the Potential for Sinkhole Occurrence, Remote Sensing Applications Laboratory. Department of Civil Engineering, University of Florida, Gainesville, FL. pp. 103.

Daly, C., Halbleib, M., Smith, J. I., Gibson, W. P., Doggett, M. K., Taylor, G. H., Curtis, J., \& Pasteris, P. P. (2008). Physiographically sensitive mapping of climatological temperature and precipitation across the conterminous United States. International Journal of Climatology, 28, 2031-2064.

Dean, D. J. (2012). The Arthur H. Robinson Map Library: Robinson projection. University of Wisconsin-Madison. Retrieved September 24, 2012, from http://www.geography.wisc.edu/maplib/robinson_projection.html

Dixon, W. N., Corneil, J. A., Wilkinson, R. C., \& Foltz, J. L. (1984). Using stem char to predict mortality and insect infestation of fire-damaged slash pines. Southern Journal of Applied Forestry, 8, 85-88.

Endries, M., Gilbert, T., \& Kautz, R. (2009). Integrated Wildlife Habitat Ranking System 2009. Florida Fish and Wildlife Conservation Commission, Tallahassee, FL pp. 23 and computer raster file. Retrieved from http:/myfwc.com/research/gis/data-maps/terrestrial/wildlife-habitat-ranking-system/

Faulkner, G. L. (1973). Geohydrology of the Cross-Florida Barge Canal Area with Special Reference to the Ocala Vicinity. U. S. Geological Survey Water Resources Investigation Report 1-73. pp. 125.

Fernald, E. A., \& Purdum, E. D. (Eds.). (1998). Water Resources Atlas of Florida. Institute of Science and Public Affairs ISBN 0-9606708-2-3, Florida State University, Tallahassee, FL, pp. 312. 
Florida Department of Transportation. (1973). Map of Lineaments in the State of Florida, State Topographic Office, Remote Sensing Section, Tallahassee, FL, p. 1.

Florida Natural Areas Inventory \& Florida Department of Natural Resources. (1990). Guide to the Natural Communities of Florida. Florida Department of Natural Resources, Tallahassee, FL, pp. 120.

Hall, L. E., \& Metcalfe, S. J. (1977). Sinkhole collapse induced by groundwater pumpage for freeze protection irrigation near Dover, Florida. In Karst Hydrology. International Association of Hydrologists, p. 1-3.

Harnett, P. R., \& Barnett, M. E. (1977). Optical rose diagrams for lineament analysis. Institution of Mining and Metallurgy, Transactions, Section B: Applied Earth Science, 86, 102-106.

Harnett, P. R., \& Barnett, M. E. (1978). Optical rose diagrams for lineament analysis. Institution of Mining and Metallurgy, Transactions, Section B: Applied Earth Science, 87, 30.

Johnston, R. H., \& Miller, J. A. (1988). Region 24, Southeastern United States. In W. Back, J. S. Rosenshein, \& P. R. Seaber (Eds.), Hydrogeology: Boulder Colorado, Geological Society of America, The Geology of North America (pp. 229-236). v. O-2.

Kincaid, T., Davies, G., Werner, C., \& DeHan, R. (2012). Demonstrating interconnection between a wastewater application facility and a first magnitude spring in a karstic watershed: Tracer study of the Southeast Farm Wastewater Reuse Facility, Tallahassee, Florida. Florida Department of Environmental Protection Florida Geological Survey Report of Investigation No. 111, Florida Geological Survey, Tallahassee, FL, pp. 202.

Koch, H. F. (1984). Sinkholes in southeastern North Carolina - A geologic phenomenon and related engineering problems. In B. F. Beck (Ed.), Proceedings of First Multidisciplinary Conference on Sinkholes, Orlando, Florida (pp. 243-248). A. A. Balkema Publishers, Accord, MA.

Krause, R. E., \& Randolph, R. B. (1989). Hydrology of the Floridan Aquifer System in southeast Georgia and Adjacent Parts of Florida and South Carolina. U. S. Geological Survey Professional Paper 1403-D. pp. $65+$ plates.

Lattman, L. H., \& Parizek, R. R. (1964). Relationship between fracture traces and the occurrence of ground water in carbonate rocks. Journal of Hydrology, 2(2), 73-91. http://dx.doi.org/10.1016/0022-1694(64)90019-8

Lewelling, B. R., Tihansky, A. B., \& Kindinger, J. L. (1998). Assessment of the Hydraulic Connection Between Ground Water and the Peace River, West-Central Florida. U. S. Geological Survey Water-Resources Investigations Report 97-4211, pp. 96.

Lines, J. P., Bernardes, S., He, J., Zhang, S., Bacchus, S. T., Madden, M., \& Jordan, J. (2012). Preferential Groundwater Flow Pathways and Hydroperiod Alterations Indicated by Georectified Lineaments and Sinkholes at Proposed Karst Nuclear Power Plant and Mines Sites. Journal of Sustainable Development, 5(12), 78-116. http://dx.doi.org/10.5539/jsd.v5n12p78

Littlefield, J. R., Culbreath, M. A., Upchurch, S. B., \& Stewart, M. T. (1984). Relationship of modern sinkhole development to large scale-photolinear features. In B. F. Beck (Ed.), Proceedings of First Multidisciplinary Conference on Sinkholes, Orlando, Florida (pp. 189-195). A. A. Balkema Publishers, Accord, MA.

Marrett, R., Ortega, O. J., \& Kelsey, C. M. (1999). Extent of power-law scaling for natural fractures in rock. Geology, 27(9), 799-802. http://dx.doi.org/10.1130/0091-7613(1999)027<0799:EOPLSF $>2.3 . C O ; 2$

McHugh, C. W., Kolb, T. E., \& Wilson, J. L. (2003). Bark beetle attacks on ponderosa pine following fire in northern Arizona. Environmental Entomology, 32, 510-522.

Menges, E. S., \& Deyrup, M. A. (2001). Postfire survival in south Florida slash pine: Interacting effects of fire intensity, fire season, vegetation, burn size, and bark beetles. International Journal of Wildland Fire, 10, 53-63.

Metcalfe, S. J., \& Hall, L. E. (1984). Sinkhole collapse induced by groundwater pumpage for freeze protection irrigation near Dover, Florida, January 1977. In B. F. Beck (Ed.), Proceedings of First Multidisciplinary Conference on Sinkholes, Orlando, Florida (pp. 29-33). A. A. Balkema Publishers, Accord, MA.

Metz, P. A., \& Lewelling, B. R. (2009). Hydrologic Conditions that Influence Streamflow Losses in a Karst Region of the Upper Peace River, Polk County, Florida: U.S. Geological Survey Scientific Investigations Report 2009-5140, pp. 82.

Miller, J. A. (1986). Hydrogeologic Framework of the Floridan Aquifer System in Florida and in Parts of Georgia, Alabama, and South Carolina. U. S. Geological Survey Professional Paper 1403-B. $91+$ plates.

Moler, P., \& Franz, R. (1987). Wildlife Values of Small, Isolated Wetlands in the Southeastern Coastal Plain. In R. R. Odum, K. A. Riddleberger, \& J. D. Ozier (Eds.), Proceedings of the $3^{\text {rd }}$ S.E. Nongame and Endangered Wildlife Symposium (pp. 234-241). Georgia Department of Natural Resources, Atlanta, GA.

National Drought Mitigation Center. (2014). http://drought.unl.edu/DroughtBasics/TypesofDrought.aspx 
Newton, J. G. (1977). Induced sinkholes - a continuing problem along Alabama highways. In J. S. Tolson, \& F. L. Doyle (Eds.), Karst Hydrogeology (pp. 303-304). University of Alabama Press, Huntsville, AL.

Norman, J. W. (1976). Photogeological fracture trace analysis as a subsurface exploration technique. Transactions of the Institution of Mining and Metallurgy (Sect. B Appl. Earth Sci.) 85, B52-62.

Ogden, A. E. (1984). Methods for describing and predicting the occurrence of sinkholes. In B. F. Beck (Ed.), Proceedings of First Multidisciplinary Conference on Sinkholes, Orlando, Florida (pp. 177-182). A. A. Balkema Publishers, Accord, MA.

Ortega, O. J., \& Marrett, R. A. (2000). Prediction of macrofracture properties using microfracture information, Mesaverde Group sandstones, San Juan basin, New Mexico. Journal of Structural Geology, 22(5), 571-588. http://dx.doi.org/10.1016/S0191-8141(99)00186-8

Ortega, O. J., Marrett, R. A., \& Laubach, S. E. (2006). A scale-independent approach to fracture intensity and average spacing measurement. AAPG Bulletin, 90(2), 193-208. http://dx.doi.org/10.1306/08250505059

Otrosina, W. J., Bannwart, D., \& Roncadori, R. W. (1999). Root-infecting fungi associated with a decline of longleaf pine in the southeastern United States. Plant and Soil, 27, 145-150. http://dx.doi.org/10.1023/A:1004645115446

Otrosina, W. J., Hess, N. J., Zamoch, S. J., Perry, T. J., \& Jones, J. P. (1997). Blue-stain fungi associated with roots of southern pine trees attacked by the southern pine beetle, Dendroctomus frontalis. Plant Disease, 81, 942-945. http://dx.doi.org/10.1094/PDIS.1997.81.8.953

Parizek, R. R. (1976). On the nature and significance of fracture trace and lineaments in carbonate and other terranes. In V. Yevjevich (Ed.), Proceedings of the U.S. Yugoslovian Symposium. Dubrovnik, June 2-7, 1975 (pp. 17-108). Karst Hydrology and Water Resources, Water Resources Publications, Ft. Collins, CO.

Peterson, R. O., \& Rumbaugh III, J.O. (2012). Hydrogeologic Impacts Observed During the January 2010 Freeze Event in Dover/Plant City, Hillsborough County, Florida. pp. 91.

Popenoe, P., Kohout, F. A., \& Manheim, F. T. (1984) Seismic-Reflection Studies of Sinkholes and Limestone Dissolution Features on the Northeastern Florida Shelf. In B. F. Beck (Ed.), Proceedings of First Multidisciplinary Conference on Sinkholes, Orlando, Florida (pp. 43-57). A.A. Balkema Publishers, Accord, MA.

Prost, G. L. (2002). Remote Sensing for Geologists: A Guide to Image Interpretation (2nd ed.). CRC Press, pp. 456.

Quinlan, J. F. (1991). Use of dyes for tracing ground water: aspects of regulation. In J. F. Quinlan, \& A. S. Stanley (Eds.), Proceedings of the Third Conference on the Hydrogeology, Ecology, Monitoring and Management of Ground Water in Karst Terranes (pp. 687-696). National Ground Water Association, Dublin, OH.

Raabe, E. A., \& Bialkowska-Jelinska, E. (2010). Thermal Imaging of the Waccasassa Bay Preserve: Image Acquisition and Processing. U.S. Geological Survey Open-File Report 2010-1120. pp. 70.

Renken, R. A., Cunningham, K. J., Shapiro, A. M., Harvey, R. W., Zygnerski, M. R., Metge, D. W., \& Wacker, M. A. (2008). Pathogen and chemical transport in the karst limestone of the Biscayne aquifer: 1. Revised conceptualization of groundwater flow. Water Resources Research, 44, 1-16. http://dx.doi.org/10.1029/2007WR006058

Renken, R. A., Cunningham, K. J., Zygnerski, M. R., Wacker, M. A., Shapiro, A. M., Harvey, R. W., Metge, D. W., Osborn, C. L., \& Ryan, J. N. (2005). Assessing the vulnerability of a municipal well field to contamination in a karst aquifer. Environmental \& Engineering Geoscience, 11(4), 319-331. http://dx.doi.org/10.2113/11.4.319

Southwest Florida Water Management District. (1996). Northern Tampa Bay Water Resources Assessment Project, Volume 1: Surface-Water/Ground-Water Interrelationships. Brooksville, FL, pp. 425.

Stewart, M. T., \& Stedje, D. (1990). Geophysical Investigation of Cypress Domes, West Central Florida. Prepared by University of South Florida Geology Department for Southwest Florida Water Management District. Brooksville, FL, pp. 103.

Stewart, M. T., \& Wood, J. (1984). Geophysical characteristics of fracture traces in the carbonate Floridan Aquifer. In B. F. Beck (Ed.), Proceedings of First Multidisciplinary Conference on Sinkholes, Orlando, Florida (pp. 225-229). A. A. Balkema Publishers, Accord, MA.

Swancar, A., Lee, T. M., \& O'Hare, T. M. (2000). Hydrogeologic setting, water budget, and preliminary analysis of ground-water exchange at Lake Starr, a seepage lake in Polk Couty, Florida. U.S. Geological Survey Water-Resources Investigations Report 00-4030. pp. 65.

Turner, R. E., Redmond A. M., \& Zedler, J. B. (2001). Count it by Acre or Function - Mitigation Adds Up to Net Loss of Wetlands. National Wetlands Newsletter, 23(6), 15-21.

United States Army Corps of Engineers, (2013). Final Areawide Environmental Impact Statement (AEIS) on Phosphate Mining in the Central Florida Phosphate District (CFPD), Tampa, FL. Retrieved from 
http://yosemite.epa.gov/oeca/webeis.nsf/viAllByDate?SearchView\&Query=\%28Central+Florida+Phosphate\%29\&Search Order $=4 \&$ SearchMax $=0 \&$ SearchWV $=$ true $\&$ SearchFuzzy $=$ true $\&$ Start $=1$

United States Army Corps of Engineers. (2012). Draft Tarmac King Road Environmental Impact Statement. Regulatory Division, Pensacola, FL. Retrieved from http://www.kingroadeis.com

United States Council on Environmental Quality, Executive Office. (1997). Considering Cumulative Effects Under The National Environmental Policy Act. pp. $64+$ App.

United States Nuclear Regulatory Commission. (2010). Draft Environmental Impact Statement for Combined Licenses (COLs) for Levy Nuclear Plant Units 1 and 2 Final Report NUREG-1941. Office of New Reactors, Publication Branch, Washington, DC 20555-0001. Retrieved from http://www.nrc.gov/reading-m/doc-collections/nuregs

United States Nuclear Regulatory Commission. (2012). Environmental Impact Statement for Combined Licenses (COLs) for Levy Nuclear Plant Units 1 and 2 Final Report NUREG-1941. Office of New Reactors, Publication Branch, Washington, DC 20555-0001. Retrieved from http://www.nrc.gov/reading-m/doc-collections/nuregs

Upchurch, S. B., \& Lawrence, F. W. (1984). Impact of ground-water chemistry on sinkhole development along a retreating scarp. In B. F. Beck (Ed.), Proceedings of First Multidisciplinary Conference on Sinkholes, Orlando, Florida (pp. 23-28). A. A. Balkema Publishers, Accord, MA.

Usery, E. L., Finn, M. P., \& Mugnier, C. J. (2009). Coordinate systems and map projections. In M. Madden (Ed-in-Chief), The Manual of Geographic Information Systems (pp. 87-112). American Society for Photogrammetry and Remote Sensing, Bethesda, Maryland.

Vernon, R. O. (1951). Geology of Citrus and Levy Counties, Florida. Florida Geological Society, Geological Bulletin No. 35, pp. 256.

Watson, J., Stedje, D., Barcelo, M., \& Stewart, M. (1990). Hydrogeologic investigation of cypress dome wetlands in well field areas north of Tampa, Florida. In Proceedings of Focus Eastern Conference, Oct. 17-19, 1990 (pp. 163-176). National Water Well Association, Dublin, OH.

Worthington, S. R. H. (2003). A comprehensive strategy for understanding flow in carbonate aquifers. In A. N. Palmer, M. V. Palmer, \& I. D. Sasowsky (Eds.), Speleogenesis and Evolution of Karst Aquifers (pp. 30-37). Karst Modeling: Special Publication 5, Karst Waters Institute, Charles Town, West VA.

Worthington, S. R. H. (2009). Diagnostic hydrogeologic characteristics of a karst aquifer (Kentucky, USA). Hydrogeology Journal, 17, 1665-1678. http://dx.doi.org/10.1007/s10040-009-0489-0

Worthington, S. R. H., Smart, C. C., \& Ruland, W. W. (2002). Assessment of Groundwater Velocities to the Municipal Wells at Walkerton. In D. Stolle, A. R. Piggott, \& J. J. Crowder (Eds.), Ground and Water: Theory to Practice (pp. 1081 - 1086). Proceedings of the $55^{\text {th }}$ Canadian Geotechnical and $3^{\text {rd }}$ Joint IAH-CNC and CGS Groundwater Specialty Conferences, Niagara Falls, Ontario, October 20-23, 2002: Southern Ontario Section of the Canadian Geotechnical Society.

\section{Copyrights}

Copyright for this article is retained by the author(s), with first publication rights granted to the journal.

This is an open-access article distributed under the terms and conditions of the Creative Commons Attribution license (http://creativecommons.org/licenses/by/3.0/). 